University of Wollongong

Research Online

Faculty of Engineering and Information

Faculty of Engineering and Information

Sciences - Papers: Part B

Sciences

2017

Experimental Investigation of Circular High-Strength Concrete Columns Reinforced with Glass Fiber-Reinforced Polymer Bars and Helices under Different Loading Conditions

Muhammad N. S Hadi

University of Wollongong, mhadi@uow.edu.au

Hayder Alaa Hasan

University of Wollongong, hah966@uowmail.edu.au

M Neaz Sheikh

University of Wollongong, msheikh@uow.edu.au

Follow this and additional works at: https://ro.uow.edu.au/eispapers1

Part of the Engineering Commons, and the Science and Technology Studies Commons

Research Online is the open access institutional repository for the University of Wollongong. For further information contact the UOW Library: research-pubs@uow.edu.au 


\title{
Experimental Investigation of Circular High-Strength Concrete Columns Reinforced with Glass Fiber-Reinforced Polymer Bars and Helices under Different Loading Conditions
}

\author{
Abstract \\ Existing design codes and guidelines do not adequately address the design of concrete columns \\ reinforced with fiber-reinforced polymer (FRP) bars. Accordingly, a number of research studies \\ investigated the behavior of FRP bar-reinforced concrete columns. However, the previous studies were \\ limited to FRP bar-reinforced normal-strength concrete (NSC) columns. In this study, the behavior of glass \\ fiber-reinforced polymer (GFRP) bar-reinforced high-strength concrete (HSC) specimens under different \\ loading conditions was investigated in terms of axial load-carrying capacity, confinement efficiency of the \\ GFRP helices, as well as the ductility and post-peak axial load-axial deformation response. The effects of \\ the key parameters such as the type of the reinforcement (steel and GFRP), the pitch of the transverse \\ helices, and the loading condition (concentric, eccentric, and four-point loading) on the performance of \\ the specimens were investigated. It was observed that the GFRP bar-reinforced HSC specimen sustained \\ similar axial load under concentric axial compression compared to its steel counterpart, but the efficiency \\ of GFRP bar-reinforced HSC specimens in sustaining axial loads decreased with an increase in the axial \\ load eccentricity. Direct replacement of steel reinforcement by the same amount of GFRP reinforcement \\ in HSC specimens resulted in about $30 \%$ less ductility under concentric axial load. However, it was found \\ that the ductility and post-peak axial load-axial deformation behavior of the GFRP bar-reinforced HSC \\ specimens can be significantly improved by providing closely spaced helices. \\ Disciplines \\ Engineering | Science and Technology Studies

\section{Publication Details} \\ Hadi, M. N. S., Hasan, H. \& Sheikh, M. Neaz. (2017). Experimental Investigation of Circular High-Strength \\ Concrete Columns Reinforced with Glass Fiber-Reinforced Polymer Bars and Helices under Different \\ Loading Conditions. Journal of Composites for Construction, 21 (4), 04017005-1-04017005-13.
}

This journal article is available at Research Online: https://ro.uow.edu.au/eispapers1/197 


\title{
Experimental Investigation on Circular High Strength Concrete Columns Reinforced with Glass Fiber-Reinforced Polymer Bars and Helices under Different Loading Conditions
}

\author{
Muhammad N. S. Hadi ${ }^{1, *}$ \\ ${ }^{1}$ Associate Professor, School of CME Engineering, University of Wollongong, Australia. \\ Email: mhadi@uow.edu.au, ${ }^{*}$ Corresponding author \\ Hayder Alaa Hasan ${ }^{2}$ \\ ${ }^{2}$ Ph.D. Candidate, School of CME Engineering, University of Wollongong, Australia. \\ Email: hah966@uowmail.edu.au \\ M. Neaz Sheikh ${ }^{3}$ \\ ${ }^{3}$ Senior Lecturer, School of CME Engineering, University of Wollongong, Australia. \\ Email:msheikh@uow.edu.au
}

\begin{abstract}
Existing design codes and guidelines do not adequately address the design of concrete columns reinforced with Fiber-Reinforced Polymer (FRP) bars. Accordingly, a number of research studies investigated the behavior of FRP bar reinforced concrete columns. However, the previous studies were limited to the FRP bar reinforced normal strength concrete (NSC) columns. In this study, the behavior of Glass Fiber-Reinforced Polymer (GFRP) bar reinforced high strength concrete (HSC) specimens under different loading conditions was investigated in terms of axial load carrying capacity, confinement efficiency of the GFRP helices as well as the ductility and post-peak axial load-axial deformation response. The effects of the key parameters such as the type of the reinforcement (Steel and GFRP), the pitch of the transverse helices and the loading condition (concentric, eccentric and four-point
\end{abstract}


loading) on the performance of the specimens were investigated. It was observed that GFRP

27 bar reinforced HSC specimen sustained almost similar axial load under concentric axial compression compared to steel counterpart, but the efficiency of GFRP bar reinforced HSC specimens in sustaining axial loads decreased with an increase in the axial load eccentricity. Direct replacement of steel reinforcement by the same amount of GFRP reinforcement in HSC specimens resulted in about $30 \%$ less ductility under concentric axial load. However, it was found that the ductility and post-peak axial load-axial deformation behavior of the GFRP bar reinforced HSC specimens can be significantly improved by providing closely spaced helices

Keywords: High strength concrete; Circular Columns; Glass Fiber-Reinforced polymer (GFRP); Bars.

\section{Introduction}

Fiber-Reinforced Polymer (FRP) bars have several advantages over steel bars in reinforcing concrete structural members. FRP bars have higher tensile strength compared to the conventional steel bars. Also, the density of the FRP bars is about $25 \%$ of the density of steel bars. In addition, FRP bars possess other attractive features such as corrosion resistance and nonmagnetic and nonconductive characteristics. FRP bars have become a competitive replacement of steel bars in reinforcing concrete structures. However, their application is still hindered due to their sensitivity to the alkaline environment and high deformability. Recently, a significant amount of research studies were conducted on the behavior of FRP bar reinforced concrete flexural members. It was reported that for the same reinforcement ratio, concrete flexural members reinforced with FRP bars experienced larger crack widths and deflections compared to those reinforced with conventional steel bars (Nanni 1993 and 
51 Toutanji HA and Saafi M. 2000). However, El-Nemr et al. (2013) reported that using high

52

53

54

strength concrete while maintaining the axial reinforcement stiffness $\left(E_{f} A_{f}\right)$ constant contributed in improving the ultimate load carrying capacity, crack width and deflection of the concrete flexural members reinforced with FRP bars. It was reported that FRP transverse reinforcement contributes in improving the shear capacity of the concrete flexural members, although the contribution of concrete to the shear capacity is lower for FRP bar reinforced concrete members compared to steel bar reinforced concrete members (Lignola et al. 2014). The results of the existing studies on FRP bar reinforced flexural concrete members were adopted in establishing several standards and design guidelines such as CAN/CSA S806-12 (CSA 2012) and ACI 440.1R-15 (ACI 2015). The compressive strength of the FRP bars is significantly lower than their tensile strength and the behavior of FRP bars differs significantly under compressive loads. Therefore, the ACI 440.1R-06 (ACI 2006) does not recommend reinforcing concrete compression members longitudinally with FRP bars, whereas CAN/CSA S806-12 (CSA 2012) ignores the contribution of FRP bars in compression for both flexural and compression members. It is noted that the ACI 440.1R-15 (ACI 2015) provides no guidelines for the use of FRP bars in reinforcing compression members.

The ACI 440.1R-06 (ACI 2006) highlighted the need for extensive research on the use of FRP bars in reinforcing concrete columns. Several research studies were conducted to investigate the behavior of FRP bar reinforced concrete columns. Paramanantham (1993) reported that GFRP longitudinal bars can only be loaded up to $30 \%$ of their ultimate strength in compression. Alsayed et al. (1999) studied the effect of the direct replacement of steel reinforcement with an equivalent amount of GFRP reinforcement on the load carrying capacity of rectangular concrete columns. It was found that the direct replacement of steel 
longitudinal bars by an equivalent amount of GFRP longitudinal bars resulted in about $13 \%$ lower load carrying capacity of columns compared to steel counterparts regardless of the type of the transverse ties (steel or GFRP). It was also found that replacing only the steel ties by an equivalent amount of GFRP ties resulted in about $10 \%$ lower load carrying capacity of columns compared to steel counterparts. Choo et al. (2006) observed that neglecting the contribution of FRP bars in the strength of concrete columns might be overly conservative. De Luca et al. (2010) reported that concrete columns could be reinforced longitudinally with GFRP bars. They observed that the GFRP ties did not contribute in increasing the capacity of the GFRP longitudinal bars in sustaining applied loads. However, the GFRP ties delayed the buckling of the GFRP longitudinal bars. Tobbi et al. (2012) reported that GFRP bars contributed by about $10 \%$ of the total axial load carrying capacity of the columns, which is about $2 \%$ less than the contribution of steel bars in the columns. Afifi et al. (2013) found that the pitch of the GFRP helices influenced the ductility of the columns more than the axial load carrying capacity. It was also found that columns reinforced transversely with smaller size GFRP helices with shorter pitch exhibited better ductility than columns reinforced with larger size helices with longer pitch. Mohamed et al. (2014) reported that concrete columns reinforced with steel bars sustained about $4 \%$ and $8 \%$ higher axial load compared to columns reinforced with CFRP and GFRP bars, respectively. It was also reported that the ductility of GFRP bar reinforced concrete columns are greater than the ductility of the CFRP bar reinforced concrete columns. Furthermore, it was reported that the axial load and bending moment capacity of steel bar reinforced columns were higher than those of GFRP bar reinforced columns. Also, the ductility of GFRP bar reinforced columns was found to be close to the ductility of steel bar reinforced columns (Hadi et al. 2016 and Karim et al. 2016). 
The aforementioned observations were based on the test results of FRP bar reinforced

101

102 concrete columns cast with normal strength concrete having compressive strengths between 20 and $44 \mathrm{MPa}$. Therefore, such observations may not be applicable for FRP bar reinforced columns constructed with concrete of much higher compressive strength. This is because the behavior of the high strength concrete (HSC) fundamentally differs from the behavior of normal strength concrete (NSC) (Cusson and Paultre 1994; Foster and Attard 1997; Razvi and Saatcioglu 1999 and Bing et al. 2001). Hence the performance of GFRP bar reinforced high strength concrete (GFRP-HSC) columns may significantly vary from the performance of GFRP bar reinforced normal strength concrete (GFRP-NSC) columns in terms of the total axial load carrying capacity, confinement efficiency of the GFRP transverse reinforcement, in addition to the ductility and post-peak axial load-axial deformation behavior of the columns.

The available research studies on FRP bar reinforced concrete columns indicate that there is a lack of experimental research on the FRP bar reinforced HSC columns. A comprehensive experimental and analytical research program has been underway at the University of Wollongong, Australia, to assess the behavior of NSC and HSC members reinforced with different types of FRP bars under static and dynamic impact loads (Hadi et al. 2016; Karim et al. 2016; Hadi and Youssef 2016; Goldston et al. 2016). This study investigates the behavior of circular HSC columns reinforced longitudinally with GFRP bars and transversely with GFRP helices under different loading conditions.

\section{Research Objectives}

This research study aims to assess the behavior of circular HSC columns reinforced with GFRP bars and helices under concentric and eccentric axial compression as well as flexural (four-point) loading. Also, this research study investigates the effect of the GFRP bars and 
helices on the maximum axial load carrying capacity, confinement efficiency, post-peak axial load-axial deformation behavior, and failure modes of the HSC columns. The findings of this study can be used to assess the feasibility of reinforcing HSC columns with FRP bars and helices.

\section{Experimental Program}

A total of 12 circular column specimens were cast and tested at the Structural Engineering laboratory of the University of Wollongong, Australia. All specimens were $210 \mathrm{~mm}$ in diameter and $800 \mathrm{~mm}$ in height. The dimensions of the tested specimens were chosen to suit the conditions and the capacity of the laboratory testing facilities. It is noted that concrete compression members having height-to-diameter ratio equal to or greater than 2.5 are considered as columns in Canadian Highway Bridge Design Code CAN/CSA S6-06 (CSA 2006). Moreover, concrete columns have been defined in the ACI 318-11 (ACI 2011) as concrete members mainly used to sustain axial load with height-to-least lateral dimension ratio greater than 3 . The height-to-diameter ratio of the specimens tested in this study was close to 4 . The height of the specimens tested in this study was adequate to provide a sufficient development length for the longitudinal reinforcing bars according to ACI 318-14 (ACI 2014).

The specimens tested in this study were divided into three groups. The specimens in the first group (Group S60) were prepared as control specimens. These specimens were reinforced with six $12 \mathrm{~mm}$ longitudinal deformed steel bars (N12) and $10 \mathrm{~mm}$ rounded steel (R10) helices with a pitch of $60 \mathrm{~mm}$. These specimens were considered as reference specimens for comparison with GFRP bar reinforced specimens. The longitudinal and transverse reinforcement of the reference specimens satisfy the requirements of ACI 318-14 (ACI 2014). 
The second group (Group G60) consisted of four specimens which were reinforced longitudinally with six \#4 (nominal diameter $=12.7 \mathrm{~mm}$ ) GFRP bars and transversely with \#3 (nominal diameter $=9.5 \mathrm{~mm}$ ) GFRP helices with a pitch of $60 \mathrm{~mm}$. The specimens in this group were designed to assess the effect of direct replacement of steel reinforcement with GFRP reinforcement. The third group (Group G30) consisted of four specimens which were reinforced longitudinally with six \#4 (nominal diameter $=12.7 \mathrm{~mm}$ ) GFRP bars and transversely with \#3 (nominal diameter $=9.5 \mathrm{~mm}$ ) GFRP helices with a pitch of $30 \mathrm{~mm}$. The specimens in this group were designed to investigate the effects of GFRP transverse reinforcement ratio on the behavior of GFRP bar reinforced HSC specimens. The first specimen of each group was tested under concentric axial load, while the second and the third specimens in each group were tested under $25 \mathrm{~mm}$ and $50 \mathrm{~mm}$ eccentric axial loads, respectively. The last specimen of each group was tested under four-point loading as beam to explore the flexural behavior of the specimen. Table 1 presents the test matrix of the specimens. Fig. 1 shows the dimensions and the reinforcement details of the tested specimens.

The test specimens are labelled (Table 1) according to the reinforcement type, pitch of helix, and loading condition. The letters " $\mathrm{S}$ " and " $\mathrm{G}$ " in the labels of the specimens represent the types of reinforcement where "S" refers to steel bars and "G" refers to GFRP bars. The number after "S" and "G" refers to the pitch of the helix. The letters "E" and "B" represent the applied loads. The letter "E" with the number afterward represent the load eccentricity: The E0 represents concentric axial loads, E25 represents $25 \mathrm{~mm}$ eccentric axial load and E50 represents $50 \mathrm{~mm}$ eccentric axial loads. The letter "B" represents the four-point loading. For instance, Specimen G60E25 is reinforced with six GFRP longitudinal bars and GFRP helix with a pitch of $60 \mathrm{~mm}$ and tested under $25 \mathrm{~mm}$ eccentric axial load. 
175 Ready mix HSC with an average 28-day compressive strength of $85 \mathrm{MPa}$ supplied by a local concrete company was used in casting all specimens on the same day. The mechanical 177 properties of the steel N12 deformed bars and steel R10 rounded bars were determined according to AS 1391-2007 (AS 2007). The \#4 GFRP longitudinal bars and \#3 GFRP helices used in this study were provided by V-Rod Australia (V-Rod 2012). The GFRP bars were sand coated to improve the bond between the bars and the concrete. The cross-sectional areas of the \#3 and \#4 GFRP bars were measured using the immersion test according to ISO 104061-1:2015 (ISO 2015) The ultimate tensile strength, corresponding strain, and the modulus of elasticity of the GFRP bars were determined according to ASTM D7205-11 (ASTM 2011). The ultimate tensile strength of the GFRP bars and the modulus of elasticity were calculated based on the cross-sectional area of the GFRP bars obtained from the immersion test. Table 2 presents the mechanical properties of the GFRP and steel bars.

\section{Specimen Fabrication and Testing Procedure}

Polyvinyl chloride (PVC) pipes with an inner diameter of $210 \mathrm{~mm}$ were used, after cutting them into lengths of $800 \mathrm{~mm}$, as molds for the casting of specimens. To avoid any movement during the pouring or vibrating the concrete, formwork fabricated from plywood was used to hold the PVC pipes in a vertical position. Steel helices were fabricated by coiling R10 steel bars. The GFRP helices were fabricated in a coil shape by the manufacturer (V-Rod 2012).

The steel and GFRP reinforcement cages were prepared by assembling the longitudinal bars and the transverse helices using steel tie wires based on the reinforcement arrangement of the specimens. The cages were then placed inside the PVC molds as shown in Fig. 2. The outer diameter of the reinforcement helices was $170 \mathrm{~mm}$ and the height of each cage was $760 \mathrm{~mm}$ to ensure a $20 \mathrm{~mm}$ concrete cover at the sides and also at the top and the bottom of the 
specimens. All specimens were cast on the same day with a batch of high strength ready mix concrete supplied by a local concrete company. Concrete vibrators were used to remove air voids and to ensure perfect compaction.

The Denison $5000 \mathrm{kN}$ testing machine was used in testing all the specimens. Before the testing, all column specimens were externally wrapped at the top and the bottom by two layers of CFRP sheets with $100 \mathrm{~mm}$ overlap to avoid premature failure during testing. The CFRP sheets were $0.5 \mathrm{~mm}$ thick and $100 \mathrm{~mm}$ wide. Both ends of the specimen were capped with high strength plaster to ensure a uniform distribution of the applied loads. Each specimen was placed vertically on the steel loading head then another steel loading head was placed on the top of the specimen. Afterwards, the specimen was placed in the testing machine and adjusted to ensure that the specimen was located at the center of the testing machine. For flexural tests, four-point loading system (consists of two steel loading rigs: the bottom and the top rigs) was used to test the specimens. Firstly, each specimen was placed horizontally on the bottom rig then the specimen and the bottom rig were positioned diagonally in the Denison testing machine and were adjusted to ensure that the specimen was located at the center of the testing machine. Afterwards, the top rig was placed on the specimen to transfer the applied loads from the testing machine to the beam specimen. Fig. 3 shows the test setup for the column and the beam specimens. The axial strain in the longitudinal bars and the hoop strain in the helices were captured using four electrical resistance strain gauges attached to reinforcement cages at the mid-height of each specimen. Two of the strain gauges were attached to the reinforcing helices at two opposite sides. The other two strain gauges were attached to two parallel longitudinal bars in a way that under eccentric axial load or four-point loading, one bar would be subjected to compression and the second bar would be subjected to tension. For the eccentrically loaded specimens, the lateral 
deformation was measured using a laser triangulation placed at the mid-height of the specimen. The midspan deflection of the specimens tested as beams was also measured using a laser triangulation fixed underneath a hole at midspan of the testing rig as shown in Fig. 3. In addition, two linear variable differential transducers LVDTs were attached to the heads of the testing machine parallel to each other for capturing the axial strain in the specimens (Fig. 3). The LVDTs and the laser triangulation were connected to an electrical data logger before the tests. The data was recorded at every 2 seconds. At the beginning of the test, each specimen was pre-loaded at a rate of $2 \mathrm{kN} / \mathrm{s}$ up to $100 \mathrm{kN}$ and then unloaded to $20 \mathrm{kN}$ at the same rate to prevent any movement in the specimens at the beginning of the test. Afterwards, displacement control loading at a rate of $0.3 \mathrm{~mm} / \mathrm{min}$ was applied until the failure of the specimen.

\section{Experimental Results}

\section{Failure Modes}

For concentrically loaded specimens, the failure in the reference Specimen S60E0 started with buckling of the longitudinal bars. Afterwards, Specimen S60E0 experienced crushing of concrete core followed by the rupture of steel helix. For the GFRP bar reinforced specimens, the failure in Specimen G60E0 was controlled by the buckling of longitudinal GFRP bars followed by the rupture of GFRP helix. This failure was due to the low confinement pressure provided by the GFRP helix. On the other hand, the failure of the well-confined Specimen G30E0 was controlled by the crushing of concrete core and the rupture of longitudinal bars and helix. Specimen G30E0 exhibited enhanced post-peak axial load-axial deformation behavior and higher axial deformation at failure than Specimen G60E0. This is because the GFRP helix in Specimen G30E0 delayed the crack propagation and restrained the longitudinal GFRP bars against buckling and allowed the specimen to fail progressively until 
the GFRP helix ruptured. Both steel and GFRP helices exhibited a sudden rupture. However, the rupture of the helices in the GFRP reinforced Specimens G60E0 and G30E0 was more sudden and more explosive compared to the control Specimen S60E0 due to the brittle nature of the GFRP bars. At the final stage, after the steel and GFRP helices ruptured and the longitudinal steel and GFRP bars buckled or ruptured, the concrete core completely crushed. At the end of the test, an inclined failure plane was observed in the crushed reign of the tested specimens. The inclined failure plane was due to the shear sliding of the upper and lower parts of the tested specimens occurred after the concrete core completely crushed. Fig. 4 shows a close-up view of the buckling and rupture of the longitudinal steel and GFRP bars as well as the rupture of steel and GFRP helices. The dashed lines represent the diagonal failure planes, which were identified by the intersection of the ruptured helices and the buckled bars.

Due to the concentration of the stresses in the middle part of the specimen tested under eccentric axial loads, all eccentrically loaded specimens exhibited spalling of the concrete cover and crushing of the concrete in the compression region accompanied by cracks on the tension face. For steel reinforced Specimens S60E25 and S60E50, the failure initiated by the buckling of the longitudinal bars in the compression side and finally, rupture of the longitudinal bars located in the tension region led to the total collapse of the specimen. On the other hand, GFRP reinforced Specimens G60E25 and G30E25 failed by rupture of the longitudinal bars and helices in the compression region. It was observed that all GFRP bars located in the compression region of the Specimen G60E25 ruptured because the transverse reinforcement provided was insufficient to prevent the rupture of the bars. However, due to the efficiency of the GFRP helix of Specimen G30E25 in restraining the longitudinal bars, only one GFRP bar located in the extreme compression region ruptured. For Specimens G60E50 and G30E50, the failure was attributed to the rupture of the helices in the 
compression side of the crushed region. In general, it was observed that specimens reinforced with larger pitch of GFRP helix failed in a more brittle and explosive manner and presented a faster rate of strength degradation after the peak load compared to the specimens with smaller pitch of GFRP helix.

A close-up view of the crushed region of the beam specimens at failure has been shown in Fig. 5. The letters "C" and "T" in Fig. 5 refer to the compression face and tension face of the beam specimens, respectively. Initially, the specimens tested as beam (S60B, G60B and G30B) were stiff and uncracked and with further loading, cracking occurred at midspan. The failure of the reference Specimen S60B was attributed to the rupture of the steel bar in the tension region. For GFRP Specimens G60B and G30B, the failure was initiated by the crushing of the concrete in the compression region and at the last stage rupture of GFRP helices resulted in a typical sudden failure followed by a substantial or total loss of the strength.

\section{Behavior of Specimens under Concentric Axial Loads}

The first specimen of each group was tested under monotonic axial compression. The axial loads and the corresponding axial deformations are listed in Table 3. Fig. 6 shows the axial load-axial deformation behavior of the concentrically loaded specimens. There were two main points to note in the axial load-axial deformation curves of the specimens: the first and the second peak loads. The first peak load represents the maximum axial load sustained by the specimens prior to the spalling of concrete cover. The second peak load represents the maximum axial load sustained by the specimens after the concrete cover completely spalled off (load carried by the confined core only). Specimens S60E0 and G60E0 did not show a second peak load. Whereas, Specimen G30E0 showed a second peak load which was higher 
than the first peak load due to the confinement pressure provided by the closely spaced GFRP helix.

Both steel and GFRP-HSC specimens showed the same initial behavior up to the first peak load. The ascending parts of the axial load-axial deformation behavior of the tested specimens were almost linear up to the beginning of the concrete cover spalling. The specimens were continuously monitored for the formation of cracks on the surface of the concrete cover. All tested specimens exhibited similar crack patterns (crack formation) under axial compressive loads during the test. Fig. 7 shows typical cracking patterns (crack formation) of the test region of Specimen G60E0 at different stages of loading during the test. These crack patterns are very similar to the crack patterns observed in Specimens S60E0 and G30E0. It was observed that the surface of the concrete cover was visually free of cracks until the specimens reached their first peak load (Figs. 7a and 7b). The maximum axial load $P_{\max }$ carried by the reference Specimen S60E0 was $2735 \mathrm{kN}$. The maximum axial load sustained by the Specimen G60E0 was $2721 \mathrm{kN}$, which is only $0.5 \%$ less than the maximum load sustained by Specimen S60E0. However, the maximum axial load carried by Specimen G30E0 was $2398 \mathrm{kN}$, which is $12 \%$ less than the maximum axial load carried by Specimen S60E0. Early spalling of the concrete cover resulted in a lower strength of Specimen G30E0 compared to the Specimens S60E0 and G60E0. It was observed that large pieces of the concrete cover of Specimen G30E0 were separated from the core during the test which was an indication that the concrete cover suffered a stability failure instead of a concrete crushing failure. The stability failure of concrete cover occurred in Specimen G30E0 due to relatively closely spaced transverse reinforcement that resulted in the formation of a natural separation plane between the core and the cover. This plane of separation was initiated by the brittleness associated with the HSC. From the readings of the strain gauges, it was found that the 
contribution of the GFRP longitudinal bars was about $6.5 \%$ of the total carrying capacity of GFRP bar reinforced HSC specimens at the first peak load. The contribution of the steel bars was about $13.6 \%$ of the total carrying capacity of steel bar reinforced HSC specimen.

Steel and GFRP bar reinforced specimens exhibited a drop in the axial load carrying capacity after the first peak load because of the spalling of the concrete cover. Ozbakkaloglu and Saatcioglu (2004) reported that the drop in the axial load carrying capacity after the first peak load is a function of the compressive strength of the concrete and the ratio between the area of the core $\left(A_{c c}\right)$ to the gross area $\left(A_{g}\right)$ of the specimen, $A_{c c} / A_{g}$. When the compressive strength increases or the ratio of the areas decreases (cover thickness increases), the drop in the axial load carrying capacity increases. For the tested specimens, the drop in the axial load carrying capacity ranged between $9-20 \%$ of the first peak load. The lower percentage of the drop in the axial load carrying capacity was observed in the well-confined Specimen G30E0. After the drop in the axial load carrying capacity, Specimen G30E0 sustained an axial load of 2196 kN, while Specimen G60E0 sustained an axial load of 2186 kN (asterisk in Fig. 6). Up to the first peak load, the lateral confinement had little or no effect on the strength of the specimens due to relatively low lateral dilation of the concrete. However, after the concrete cover spalled off, micro-cracking developed inside the core causing the core to dilate and activate the lateral confining pressure by the helical reinforcement. After the first peak load, the behavior of the tested specimens differed depending on the characteristics of the confined concrete core. As a result of the lateral confinement pressure, the axial load-axial deformation curve of the tested specimens gained an enhancement in the strength while the concrete cover gradually disappeared (Fig. 7c). However, the post-peak axial load-axial deformation behavior of Specimen G60E0 was characterized by a loss of about $50 \%$ of the total axial load carrying capacity followed by a catastrophic failure immediately after the specimen reached 
the peak axial load. For the well confined Specimen G30E0, it was found that the hoop strain in the GFRP helix at the first peak load was less than $5 \%$ of the ultimate tensile strength. However, after the cover spalled off the GFRP helix of Specimen G30E0 was fully activated. As a result of the high tensile strength of the GFRP helix and the linear elastic stress-strain relationship of the GFRP bars, Specimen G30E0 experienced a second peak axial load higher than the first peak axial load (Fig. 6). The axial load carried by Specimen G30E0 at the second peak was $2593 \mathrm{kN}$, which is about $8.0 \%$ higher than the first peak axial load. Afterwards, crushing in the concrete core then buckling or rupture of the longitudinal bars or rupture in the helices occurred and caused a total collapse of the specimens (Fig. 7d).

The ductility of the tested specimens was calculated based on the areas under the loaddeformation curves. Ductility index denoted as $I_{5}$ was used as an indication for the ductility of the specimens. The ductility was obtained by dividing the area under the load-deformation curve up to $3 \delta_{y}$ to the area under the curve up to $\delta_{y}$ (Foster and Attard 1997). The $\delta_{y}$ represents the yield deformation corresponding to the intersection point of a horizontal line from the first peak load of the tested specimens and an extension line between the origin point and the point representing 0.75 times the first peak load. The load corresponding to the yield deformation is defined as the yield load which represents the approximate limit of the elastic behavior of the specimens (Pessiki and Peironi 1997). Specimen G60E0 exhibited about $30 \%$ lower ductility compared to the reference Specimen S60E0. However, increasing the transverse reinforcement in Specimen G30E0 resulted in a higher ductility of about 35\% in comparison with the reference Specimens S60E0. The ductility of the concentrically loaded specimens is reported in Table 3. 
374 A total of six specimens (the second and third specimens of each group) were tested under eccentric axial compression. Three specimens tested under $25 \mathrm{~mm}$ eccentric axial compression (S60E25, G60E25 and G30E25) and three specimens tested under $50 \mathrm{~mm}$ eccentric axial compression (S60E50, G60E50 and G30E50). In general, steel bar reinforced HSC specimens tested under $25 \mathrm{~mm}$ and $50 \mathrm{~mm}$ eccentric axial loads showed one peak load, which represented the maximum load carried by the specimen before the spalling of concrete cover. Due to the high tensile strength of the GFRP helices compared to the steel helices and the linear elastic stress-strain relationship of the GFRP helices, the GFRP bar reinforced HSC specimens tested under $25 \mathrm{~mm}$ and $50 \mathrm{~mm}$ eccentric axial load experienced a second peak load. However, the second peak load was lower than the first peak load due to the axial load eccentricity.

Table 3 reports the experimental results for the specimens tested under eccentric axial load with $25 \mathrm{~mm}$ eccentricity. Fig. 8a illustrates the axial load-axial deformation and axial loadlateral deformation behavior of the specimens tested under $25 \mathrm{~mm}$ eccentric axial load. Similar to the concentrically loaded specimens, the ascending parts of the axial load-axial deformation behavior of the specimens tested under $25 \mathrm{~mm}$ eccentric axial load showed an approximately linear behavior up to the peak load. It was found that at the first peak axial load, the position of the neutral axis for the specimens tested under $25 \mathrm{~mm}$ eccentric axial load was near the tension side of the tested specimens. Therefore, the cross-section of the specimens tested under $25 \mathrm{~mm}$ eccentric axial load was still fully compressed and all the longitudinal bars were under compression. The maximum load carried by the reference 
Specimen G30E25 was $1572 \mathrm{kN}$, which is $1.6 \%$ less than the Specimen G60E25. Despite the premature spalling of the concrete cover for Specimen G30E25 occurred due to the stability failure of the concrete cover, the effect of the premature concrete cover spalling on the total axial load carrying capacity of Specimen G30E25 was not significant compared to Specimen G30E0, which was tested under concentric axial load. The reason for such an insignificant effect is attributed to the tendency of concrete cover on the compression side of Specimen G30E25 to buckle towards the core when subjected to eccentric axial load and, hence, the concrete cover was constrained against buckling.

After the peak load, the spalling of the concrete cover was more gradual for specimens tested under $25 \mathrm{~mm}$ eccentric axial loads than for concentrically loaded specimens. Firstly, the cover spalled off at the compression face of each specimen after the peak load. At latter stages of loading the cracks in the concrete cover extended to the faces at the sides accompanied by cracking at the tension face. The drop in the axial load carrying capacity of specimens, resulting from the spalling of the concrete cover after peak load varied from $14 \%$ to $19 \%$ of the peak load. The axial load sustained by Specimen G60E25 after the cover spalling was $1294 \mathrm{kN}$, while Specimen G30E25 carried $1338 \mathrm{kN}$ after the cover spalling. This clearly demonstrates the effect of the lateral confinement on the strength of the concrete core of the specimens. After the concrete cover spalled off, Specimens S60E25 and G60E25 did not exhibit an increase in the axial load carrying capacity due to the inadequately confined concrete core which was insufficient to compensate for the loss of the concrete cover in both specimens. The reduced pitch of the helix in Specimen G30E25 resulted in an enhancement in the post-peak axial load-axial deformation behavior compared to Specimens S60E25 and G60E25. Specimen G30E25 showed an increase in the axial load carrying capacity which contributed to the compensation of about $50 \%$ of the drop in the axial load 
carrying capacity resulted from the spalling of the concrete cover. In the post-peak region, the peak axial loads, respectively. Similar behavior was reported in Lignola et al. (2007) for eccentrically loaded CFRP sheet confined normal strength concrete columns. Specimens G60E25 and G30E25 continued to carry the axial load until failure at corresponding axial deformations of $8.31 \mathrm{~mm}$ and $10.17 \mathrm{~mm}$, respectively. This behavior reflects the efficiency of the GFRP helices in confining HSC columns.

The test results of specimens tested under $50 \mathrm{~mm}$ eccentric axial load are presented in Table

3.The axial load-axial deformation behavior of specimens tested under $50 \mathrm{~mm}$ eccentric axial loads is shown in Fig. 8b. The axial load-lateral deformation behavior for these specimens is also shown in Fig. 8b. Unlike the specimens tested under concentric and $25 \mathrm{~mm}$ eccentric loads, the axial load-axial deformation curves of the specimens tested under $50 \mathrm{~mm}$ eccentric axial load are slightly curved in the ascending portions up to the peak load. As the eccentricity of the axial load increased to $50 \mathrm{~mm}$, the neutral axis drifted towards the middle of the cross-section of the specimens. As a result, half of the longitudinal bars were under tension and half of the longitudinal bars were under compression. Increasing the load eccentricity to $50 \mathrm{~mm}$ also resulted in a decrease in the peak load of the specimens and an increase in the lateral deformation at failure. The maximum axial load carried by the control Specimen S60E50 was 1158 kN. The axial load sustained by Specimens G60E50 was 1023 $\mathrm{kN}$, which is about $12 \%$ less than S60E50. The total axial load carrying capacity of Specimen the first peak was 0.5, 10 and 12\% less than the axial load carried by Specimens S60E0, 
S60E25, S60E50, respectively. This indicated that the capability of GFRP bar reinforced HSC specimens in carrying axial loads decreased as the load eccentricity increased. Also, the drop in the axial load carrying capacity after peak load increased as the load eccentricity increased. Specimens S60E50 and G30E50 exhibited a drop in the axial load carrying capacity of about 20 and $22 \%$, respectively, while a significant drop of $33 \%$ in the axial load carrying capacity was experienced by Specimen G60E50. In the post-peak region, the control specimen showed similar behavior to the specimen tested under $25 \mathrm{~mm}$ eccentric axial load (Specimen S60E25), with a gradual decrease in the sustained load up to the failure due to helix rupture. In contrast, both Specimens G60E50 and G30E50 exhibited a slight increase in the axial load up to the failure. The concentrically loaded Specimens G30E0 exhibited a second peak load, whereas Specimens G30E25 and G30E50 showed no second peak load. This was an indication that the efficiency of the GFRP helices in confining HSC columns also decreased with increasing the axial load eccentricity.

As the eccentricity of the axial load increased (that is, neutral axis drifted to inside the section of the tested specimens), it was observed that Specimens G60E25 and G60E50 achieved relatively greater ductility compared to the concentrically loaded Specimen G60E0 due to the tensile strength of the GFRP bars. In contrast, the ductility of the Specimens S60E25 and S60E50 was slightly lower than the ductility of the concentrically loaded Specimen S60E0 even though the eccentricity of the axial load was increased. This observation could be explained by taking into consideration the effect of the buckling of the longitudinal steel bars which is particularly significant for specimens tested under axial loads with small eccentricities. It was also found that reducing the pitch of the transverse reinforcement in the 
47232 and 25\% compared to the reference Specimens S60E25 and S60E50, respectively, as 473 shown in Table 3.

\section{Behavior of Specimens under Four-Point Loading}

476 The last specimen of each group was tested as a beam under four-point loading over a clear span $(l)$ of $700 \mathrm{~mm}$ with a shear span of $233.3 \mathrm{~mm}$. It is noted that the response of the beam specimens might not be due to the pure bending, as the shear span-to-depth ratio of specimens was less than 1.5. However, the dimensions of the specimens tested under fourpoint loading were kept the same as the other specimens tested under concentric and eccentric axial loads for uniformity and consistency. Due to the high tensile strength of the GFRP bars and the relatively small span-to-depth ratio of the tested specimens, two layers of CFRP sheets were applied in the shear span of Specimens G60B and G30B to avoid shear failure and to minimize the effect of the shear-induced deflection at midspan. CFRP sheets were also applied in the shear span of the control Specimen S60B to ensure consistent comparisons with the GFRP reinforced specimens. It was observed that the initial branch of the loaddeflection behavior of both steel and GFRP bar reinforced specimens was approximately linear up to the peak load. The reference Specimen S60B experienced one peak load with a maximum load of $309 \mathrm{kN}$. Specimen G60B exhibited two peak loads, the maximum load at the first peak was $321 \mathrm{kN}$ which is about $4 \%$ higher than the maximum load of the Specimen S60B. Beyond the first peak load, Specimen G60B showed an almost linear post-peak axial load-axial deformation behavior and reached a second peak load due to the high tensile strength and the elastic stress-strain relationship of the GFRP bars and GFRP helix. The maximum load sustained by Specimen G60B at the second peak was $517 \mathrm{kN}$. Specimen G30B exhibited similar load-deflection behavior as in Specimen G60B. However, reducing the pitch of the GFRP helix resulted in an increase of about 9 and $23 \%$ in the first and the 
second peak loads, respectively, compared to the Specimen G60B. The GFRP bar reinforced HSC specimens experienced an almost linear load-longitudinal bar strain relationships up to failure regardless the pitch of the transverse GFRP helices. Similar observation was also reported in Ali et al. (2016). The strain in the longitudinal GFRP bars and the hoop strain in the GFRP helices measured at ultimate load indicated that the failure of the GFRP bar reinforced HSC specimens occurred due to the rupture of the GFRP helices rather than the rupture of GFRP bars. The ductility of Specimens G60B and G30B was higher than the ductility of the reference Specimen S60B by about 12 and $32 \%$, respectively. Table 4 summarizes the results of the flexural tests. The load-midspan deflection behavior of the tested specimens tested under four-point loading is shown in Fig. 9.

507

\section{Interaction Diagrams}

In this study, the experimental axial load-bending moment $(P-M)$ interaction diagrams were plotted for Groups S60, G60 and G30. Four points were used to draw the $P-M$ curve for each group of specimens. Each point consists of two components: the axial load and the corresponding bending moment. The first point on the $P-M$ curve represents the specimen subjected to a concentric axial load. The second and the third points represent specimens tested under 25 and $50 \mathrm{~mm}$ eccentric axial load, respectively. The fourth point represents the specimen tested under four-point loading. Most of the specimens tested in this study (especially the specimens tested under eccentric axial loads) showed no second peak load greater than the first peak load. Therefore, the first peak load was considered the maximum axial load carrying capacity for the design purposes. Thus, the first peak load sustained by the tested specimens under different loading conditions was used in establishing the $P-M$

520 interaction diagrams. It is noted that reducing the pitch of the GFRP helices did not considerably change the $P-M$ interaction diagrams of the GFRP-HSC specimens since the 
522 passive confinement provided by the GFRP helices at the first peak load was not activated

523 considerably. However, using the first peak load in establishing the $P-M$ interaction

524 diagrams of the GFRP-HSC specimens is considered safer especially for GFRP-HSC

525 specimens subjected to a combination of axial compression load and bending moment

526 (eccentric axial load). The axial load was recorded by the testing machine. For eccentrically

527 loaded specimens, the bending moment, including the secondary moment was calculated by

528 Eq. 1. For specimens tested as beams, the value of the bending moment was calculated by Eq.

5292

530

531

$$
\mathrm{M}=\mathrm{P}(\mathrm{e}+\delta)
$$

532

$$
M=\frac{P l}{6}
$$

Where $P$ is the first peak load and $\delta$ is the corresponding lateral deformation, $e$ is the load eccentricity and $l$ is the clear span between the supports of the beam specimens.

537

538 It was observed that specimens reinforced with conventional steel bars experienced higher axial load and moment capacity under concentric and eccentric axial loads compared to 540 GFRP bar reinforced specimens due to the greater elasticity modulus of the steel 541 reinforcement. The peak axial load-bending moment diagram of Group G30 was lower than

542 Group G60 under concentric and eccentric loads due to the early spalling of the concrete cover which led to lower than anticipated axial load carrying capacity. Similar observation was reported in Cusson and Paultre (1994) and Foster et al. (1998). GFRP specimens (G60B and G30B) experienced higher bending moment capacity under four-point loading. Fig. 10 
546 shows the experimental axial load-bending moment $(P-M)$ interaction diagrams of the 547 Groups S60, G60 and G30.

549 The analytical axial load-bending moment diagrams of the GFRP bar reinforced HSC circular specimens were developed by using a layer-by-layer integration technique. The interaction diagrams of the GFRP-HSC specimens were established based on the same assumptions adopted for steel bar reinforced concrete sections: the strength of the concrete in tension is neglected and a perfect bond exists between the concrete and the embedded GFRP bars. Sections orthogonal to the axis of the bending are plane prior and after bending. Hence, the strain along the cross-section of the specimen and the strain in the reinforcement layers are proportional to the depth of the natural axis.

The cross-section of the GFRP bar reinforced HSC specimens was firstly divided into $n$ number of small concrete strips $s_{i}$ having a length of $b_{s_{i}}$ and a width of $h / n$ as shown in Fig. 11, where $h$ is the cross-section diameter of the GFRP bar reinforced HSC specimens.

561 Afterwards, the concrete strain $\varepsilon_{c, s_{i}}$ at the center of each single concrete strip $d_{c, s_{i}}$ and the 562 GFRP reinforcement strain $\varepsilon_{f, i}$ at the center of each reinforcement layer $d_{f, i}$ were 563 determined assuming a linear strain distribution along the cross-section of the specimens, as mentioned above. The ultimate compressive strain of the concrete $\varepsilon_{u}$ at the extreme compression fiber of the specimen cross-section was taken equal to 0.003 according to ACI 318-14 (ACI 2014). A linear elastic stress-strain relationship was used in calculating the

567 stresses in each GFRP reinforcement layer $f_{f, i}$. Thorenfeldt et al. (1987) developed an unconfined concrete stress-strain relationship for concrete with compressive strength ranging between 15 to $125 \mathrm{MPa}$ based on a model proposed by Popovics (1973). The stress-strain 
570

571

572

573

574

575

576

577

578

579

580

581

582

583

584

585

586

587

588

589

590

591

592

593

594

595

89

model proposed by Thorenfeldt et al. (1987) was used in computing the stresses in each concrete strips $f_{c, s_{i}}$ as:

$$
\begin{gathered}
f_{c}=\frac{f_{c}^{\prime} x r}{r-1+x^{k r}} \\
x=\frac{\varepsilon_{c}}{\varepsilon_{0}}
\end{gathered}
$$

where $f_{c}$ and $\varepsilon_{c}$ are the compressive stress and the corresponding strain of the concrete. The $f_{c}^{\prime}$ represents the maximum compressive strength of the concrete obtained from testing concrete cylinders and $\varepsilon_{0}$ represents the strain in concrete when $f_{c}$ reaches $f_{c}^{\prime}$. The $r$ is the concrete stress-strain curve fitting factor, while $k$ is a factor that controls the slope of the ascending and the descending parts of the concrete stress strain curve. The values of $\varepsilon_{0}, r$ and $k$ were determined using Eq. 5 through Eq. 8 according to Collins and Mitchell (1991):

$$
\varepsilon_{0}=\frac{f_{c}^{\prime}}{E_{c}}\left(\frac{r}{r-1}\right)
$$

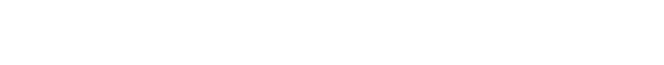

$$
r=0.8+\left(\frac{f_{c}^{\prime}}{17}\right)
$$

For $\left(\varepsilon_{c} / \varepsilon_{0}\right) \leq 1.0$

$$
k=1.0
$$

For $\left(\varepsilon_{c} / \varepsilon_{0}\right)$ greater than 1.0

$$
k=0.67+\left(\frac{f_{c}^{\prime}}{62}\right) \geq 1.0
$$

The elastic modulus of the HSC was obtained from Eq. 9 (ACI 363-10 (ACI 2010) : 


$$
E_{c}=3.32 \sqrt{f_{c}^{\prime}}+6.9 \text { (in GPa) }
$$

598

599

Afterwards, the stresses were integrated over the entire cross-sectional area to compute the 600 resultant force in each concrete strips $C_{S_{i}}$ and in each GFRP reinforcement layer $F_{f, i}$ and 601 the corresponding bending moment. For precise results, the width of the concrete strips should be considerably small. In this study, the width of the concrete strips was taken equal to 603 $1 \mathrm{~mm}$. The approach explained above was also used in establishing the interaction diagram of 604 the reference steel bar reinforced HSC specimens in Group S60, assuming that the stress605 strain relationship of the steel longitudinal bars is elastic-plastic until the failure.

606

607 Since the behavior of the FRP bars under compression load is complicated, the CAN/CSA 608 S806-12 (CSA 2012) recommended neglecting the contribution of the FRP bars when used as 609 longitudinal reinforcement in concrete columns. The ACI 440.1R-15 (ACI 2015) provided no guidelines in that regard as mentioned above. In this study, the contribution of the GFRP longitudinal bars was taken into account when establishing the $P-M$ interaction diagrams in order to further investigate the effect of GFRP bars on the strength capacity of the GFRPHSC columns. Fig. 12 compares the analytical and the experiment $P-M$ interaction diagrams for the GFRP and steel bar reinforced specimens tested in this study. It was found that the analytical results of the specimens tested under concentric and eccentric axial loads were in good agreement with the experimental results when the contribution of the GFRP bars located in the compression region was taken into consideration. The experimental bending moments of the specimens tested under four-point loading were relatively greater than the calculated bending moments. The difference between the predicted and the experimental bending moments of the specimens tested under four-point loading was attributed to the fact 
that the response of the specimens might not be due to the pure bending, as the shear span-todepth ratio of the specimens was less than 1.5.

\section{Conclusions}

This research study is part of an ongoing research program at the University of Wollongong, Australia that aims to investigate the complex mechanisms of the NSC and HSC members reinforced with different types of FRP bars under static and dynamic impact loads. This study reported the results of twelve HSC column specimens reinforced longitudinally with GFRP bars and confined transversely with GFRP helices tested under concentric and eccentric axial load as well as four-point loading. Based on the test results, the following conclusions can be drawn:

1. It was found that GFRP bar reinforced HSC specimen sustained similar axial load under concentric axial compression compared to HSC specimen reinforced with the same amount of steel reinforcement. However, the efficiency of the GFRP bar reinforced HSC specimens in sustaining axial load decreased by about $12 \%$ for the change in the loading condition from concentric to $50 \mathrm{~mm}$ eccentric axial load.

2. It was observed that the contribution of the GFRP longitudinal bars in the total carrying capacity of GFRP bar reinforced HSC specimens was about half the contribution of the steel bars in total carrying capacity of steel bar reinforced HSC specimen under concentric axial load. It was also found that the analytical and the experimental results were in good agreement when the load sustained by the GFRP bars located in the compression region was taken into account.

3. Under axial compression, the direct replacement of steel bars with the same amount of GFRP bars resulted in a loss of about $50 \%$ in the total axial load carrying capacity 
followed by a catastrophic failure immediately after the specimen reached the peak axial load.

4. Group G60 specimens showed no second peak load under concentric and eccentric axial diameter ratio of 3.8. The size effect of the specimens on the experimental investigations has not been considered. Hence, the above conclusions should be translated with cautions for 


\section{Acknowledgments}

670 The authors express special thanks to the technical officers at the High Bay Laboratories of 671 the University of Wollongong, especially Messrs. Ritchie Mc Lean, Richard Gasser and

672 Fernando Escribano, for their help in conducting the experimental program of this study. 673 Also, the second author would like to acknowledge the Iraqi Government and the University 674 of Wollongong for the support of his full Ph.D. scholarship. The second author also thanks 675 his parents for their loving support.

676

\section{References}

678 ACI (American Concrete Institute). (2010). "Report on high strength concrete." ACI 363R-10, Farmington Hills, MI.

ACI (American Concrete Institute). (2006). "Guide for the design and construction of 681 structural concrete reinforced with FRP bars." ACI: 440.1R-06, Farmington Hills, MI.

ACI (American Concrete Institute). (2011). "Building code requirements for structural concrete." ACI: 318M-11, Farmington Hills, MI.

ACI (American Concrete Institute). (2014). "Bulding code requirements for structural concrete " ACI: 318M-14, Farmington Hills, MI.

ACI (American Concrete Institute). (2015). "Guide for the design and construction of structural concrete reinforced with FRP bars." ACI: 440.1R-15, Farmington Hills, MI.

Afifi, M., Mohamed, H., and Benmokrane, B. (2013). "Axial capacity of circular concrete

Ali, A. H., Mohamed, H. M., and Benmokrane, B. (2016). "Shear behavior of circular concrete members reinforced with GFRP bars and spirals at shear span-to-depth ratios 
between 1.5 and 3.0." Journal of Composites for Construction, [DOI: 10.1061/(ASCE)CC.1943-5614.0000707.].

Alsayed, S. H., Al-Salloum, Y. A., Almusallam, T. H., and Amjad, M. A. (1999). "Concrete columns reinforced by GFRP rods." 4th Int. Symp. on Fiber-Reinforced Polymer Reinforcement for Reinforced Concrete Structures SP-188, C. W. Dolan, S. H. Rizkalla, and A. Nanni, eds., American Concrete Institute, Farmington Hills, MI,, 103-112.

AS (Australian Standard). (2007). "Metalic materials-tensile testing at amient temperature." AS: 1391-07, Sydney, NSW, Australia.

ASTM (American Society for Testing and Materials). (2011). "Standard test method for tensile properties of fiber reinforced polymer matrix composite bars." ASTM D720511, West Conshohocken, PA.

Bing, L., Park, R., and Tanaka, H. (2001). "Stress-strain behavior of high-strength concrete confined by ultra-high- and normal-strength transverse reinforcements." $A C I$ Structural Journal, 98(3), 395-406.

Choo, C. C., Harik, I. E., and Hans, G. (2006). "Strength of rectangular concrete columns reinforced with fiber-reinforced polymer bars." ACI Structural Journal, 103(3), 452459.

Collins, M. P., and Mitchell, D. (1991). "Prestressed concrete structures" Prentice Hall, Englewood Cliffs,766 pp.

CSA (Canadian Standards Association). (2006). "Canadian highway bridge design code." CAN/CSA S6-6, Rexdale, ON, Canada.

CSA (Canadian Standards Association). (2012). "Design and construction of building components with fiber reinforced polymers." CAN/CSA S806-12, Rexdale, ON, Canada. 
Cusson, D., and Paultre, P. (1994). "High-strength concrete columns confined by rectangular ties." Journal of Structural Engineering, 120(3), 783-804.

De Luca, A., Matta, F., and Nanni, A. (2010). "Behavior of full-scale glass fiber-reinforced polymer reinforced concrete columns under axial load." ACI Structural Journal, 107(05), 589-596.

El-Nemr, A., Ehab A. Ahmed, and Benmokrane, B. (2013). "Flexural behavior and serviceability of normal-and high-strength concrete beams reinforced with glass fiberreinforced polymer bars." ACI Structural Journal, 110(6), 1077-1087.

Foster, S. J., and Attard, M. M. (1997). "Experimental tests on eccentrically loaded high strength concrete columns." ACI Structural Journal, 94(3), 295-303.

Foster, S. J., Liu, J., and Sheikh, S. (1998). "Cover spalling in HSC columns loaded in concentric compression." Journal of Structural Engineering, 124(12), 1431-1437.

Goldston, M., Remennikov, A., and Sheikh, M. N. (2016). "Experimental investigation of the behaviour of concrete beams reinforced with GFRP bars under static and impact loading." Engineering Structures, 113, 220-232.

Hadi, M., and Youssef, J. (2016). "Experimental investigation of GFRP-reinforced and GFRP-encased square concrete specimens under axial and eccentric load, and fourpoint bending test." Journal of Composites for Construction, [DOI: 10.1061/(ASCE)CC.1943-5614.0000675.].

Hadi, M., Karim, H., and Sheikh, M. (2016). "Experimental investigations on circular concrete columns reinforced with GFRP bars and helices under different loading conditions." Journal of Composites for Construction, [DOI:10.1061/(ASCE)CC.1943$5614.0000670]$. 
ISO (International Organization for Standardization). (2015). "Fibre-reinforced polymer (FRP) reinforcement of concrete: Test methods: Part 1: FRP bars and grids." ISO: 10406-1-05, Switzerland.

Karim, H., Sheikh, M. N., and Hadi, M. N. S. (2016). "Axial load-axial deformation behaviour of circular concrete columns reinforced with GFRP bars and helices." Construction and Building Materials, 112, 1147-1157.

Lignola, G. P., Jalayer, F., Nardone, F., Prota, A., and Manfredi, G. (2014). "Probabilistic design equations for the shear capacity of RC members with FRP internal shear reinforcement." Composites Part B: Engineering, 67, 199-208.

Lignola, G. P., Prota, A., Manfredi, G., and Cosenza, E. (2007). "Deformability of reinforced concrete hollow columns confined with CFRP." ACI Structural Journal, 104(5), 629.

Mohamed, H., Afifi, M., and Benmokrane, B. (2014). "Performance evaluation of concrete columns reinforced longitudinally with FRP bars and confined with FRP hoops and spirals under axial load." Journal of Bridge Engineering, 19(7), 04014020.

Nanni, A. (1993). "Flexural behavior and design of RC members using FRP reinforcement." Journal of Structural Engineering, 119(11), 3344-3359.

Ozbakkaloglu, T., and Saatcioglu, M. (2004). "Rectangular stress block for high-strength concrete." ACI Structural Journal, 101(4), 475-483.

Paramanantham, N. S. (1993). "Investigation of the behavior of concrete columns reinforced with fiber-reinforced plastic rebars." M.Sc., Lamar Univ., Beaumont, TX.

Pessiki, S., and Pieroni, A. (1997). "Axial load behavior of lLarge scale spirally reinforced high strength concrete columns." ACI Structural Journal, 94(3).

Popovics, S. (1973). "A numerical approach to the complete stress-strain curve of concrete." Cement and Concrete Research, 3(5), 583-599. 
Razvi, S. R., and Saatcioglu, M. (1999). "Circular high-strength concrete columns under concentric compression." ACI Structural Journal, 96(5), 817-826.

Thorenfeldt, E., Tomaszewicz, A. and Jensen, J. J. (1987). "Mechanical properties of high strength concrete and Application to design," Proceedings of the Symposium: Utilization of High-Strength Concrete, Stavanger, Norway, 149-159.

Tobbi, H., Farghaly, A. S., and Benmokrane, B. (2012). "Concrete columns reinforced longitudinally and transversally with glass fiber-reinforced polymer bars." $A C I$ Structural Journal, 109(4), 551-558.

Toutanji, H., and Saafi, M. (2000). "Flexural behavior of concrete beams reinforced with glass fiber-reinforced polymer (GFRP) bars." ACI structural journal, 97(5), 712-719.

V-Rod. (2012). "Composite reinforcing rods tecnical data sheet." Large Bay SA, Australia.

6

(1)

8

9

(1)

1

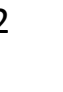

83

84


789

790

791

792

793

794

795

796

797

798

799

800

801

802

803

804

805

806

807

808

809

810

811

812

813

814

Page 33 of 38 
816 Fig. 1: Dimensions and reinforcement details of the tested specimens.

817 Fig. 2: Specimen Fabrication: (a) PVC molds and the wooden formwork; (b) steel and GFRP 818 cages and (c) GFRP and steel cages inside the PVC molds.

819 Fig. 3: Testing of the specimens: (a) test setup of column specimens; (b) loading head setup for 820 concentrically loaded column specimens; (c) loading head setup for column specimens tested 821 under $25 \mathrm{~mm}$ eccentric axial load; (d) loading head setup for column specimens tested under 50 $822 \mathrm{~mm}$ eccentric axial load and (e) test setup of the beam specimens.

823 Fig. 4: Failure of column specimens: (a) buckling of the longitudinal steel bars and rupture of 824 the steel helix; (b) buckling and rupture of longitudinal GFRP bars and (c) rupture of the 825 GFRP helix.

826 Fig. 5: Failure modes of the beam specimens

827 Fig. 6: Axial load- axial deformation behavior of the concentrically loaded specimens.

828 Fig. 7: Specimen G60E0 at different loading stages: (a) at the beginning of the test; (b) after 829 the first peak load; (c) spalling of the concrete cover and (d) after failure.

830 Fig. 8: Axial load-axial deformation and axial load-lateral deformation behavior of the specimens tested under: (a) $25 \mathrm{~mm}$ eccentric axial load and (b) $50 \mathrm{~mm}$ eccentric axial load.

832 Fig. 9: Load-midspan deflection behavior of the specimens tested under four-point loading.

833 Fig. 10: Experimental axial load-bending moment $(P-M)$ interaction diagrams.

834 Fig. 11: Stress-strain distribution for $P-M$ interactions of GFRP-HSC cross-section using layer-by-layer integration.

836 Fig. 12: Experimental and analytical axial load-bending moment $(P-M)$ interaction diagrams 837 for: (a) Group S60; (b) Group G60 and (c) Group G30. 
Table 1: Test matrix

\begin{tabular}{|c|c|c|c|c|c|}
\hline Group & Specimen & $\begin{array}{c}\text { Reinforcement } \\
\text { Type }\end{array}$ & $\begin{array}{l}\text { Longitudinal } \\
\text { reinforcement }\end{array}$ & $\begin{array}{l}\text { Transverse } \\
\text { reinforcement }\end{array}$ & $\begin{array}{l}\text { Load Eccentricity } \\
(\mathrm{mm})\end{array}$ \\
\hline \multirow{4}{*}{ S60 } & S60E0 & \multirow{4}{*}{ Steel } & \multirow{4}{*}{$6 \mathrm{~N} 12$} & \multirow{4}{*}{ R10@60 mm } & 0 \\
\hline & S60E25 & & & & 25 \\
\hline & S60E50 & & & & 50 \\
\hline & S60B & & & & Four-point loading \\
\hline \multirow{4}{*}{ G60 } & G60E0 & \multirow{4}{*}{ GFRP } & \multirow{4}{*}{$6 \# 4$} & \multirow{4}{*}{ \#3@60mm } & 0 \\
\hline & G60E25 & & & & 25 \\
\hline & G60E50 & & & & 50 \\
\hline & G60B & & & & Four-point loading \\
\hline \multirow{4}{*}{ G30 } & G30E0 & \multirow{4}{*}{ GFRP } & \multirow{4}{*}{$6 \# 4$} & \multirow{4}{*}{ \#3@30 mm } & 0 \\
\hline & G30E25 & & & & 25 \\
\hline & G30E50 & & & & 50 \\
\hline & G30B & & & & Four-point loading \\
\hline
\end{tabular}

842

843

844

845

846

847

848

849

850

851

852

853

854

855

856

857 
Table 2: Mechanical properties of GFRP and steel bars

\begin{tabular}{ccccccc}
\hline Bar Type & Bar size & $\begin{array}{c}\text { Nominal } \\
\text { Diameter } \\
(\mathrm{mm})\end{array}$ & $\begin{array}{c}\text { Area } \\
\left(\mathrm{mm}^{2}\right)\end{array}$ & $\begin{array}{c}\text { Tensile } \\
\text { Strength } \\
(\mathrm{MPa})\end{array}$ & $\begin{array}{c}\text { Strain corresponding } \\
\text { to tensile strength } \\
(\mathrm{mm} / \mathrm{mm})\end{array}$ & $\begin{array}{c}\text { Elastic } \\
\text { modulus } \\
(\mathrm{GPa})\end{array}$ \\
\hline \multirow{2}{*}{ Steel } & $\mathrm{N} 12$ & 12 & 113 & $550^{\mathrm{b}}$ & 0.0027 & 200 \\
& $\mathrm{R} 10$ & 10 & 78.5 & $420^{\mathrm{b}}$ & 0.0022 & 190 \\
\cline { 2 - 7 } GFRP & $\# 3$ & $11^{\mathrm{a}}$ & $95^{\mathrm{a}}$ & $1320^{\mathrm{c}, \mathrm{d}}$ & 0.0231 & $57^{\mathrm{d}}$ \\
& $\# 4$ & $145^{\mathrm{a}}$ & $165^{\mathrm{a}}$ & $1190^{\mathrm{c}, \mathrm{d}}$ & 0.0228 & $52^{\mathrm{d}}$ \\
\hline
\end{tabular}

860

${ }^{a}$ Measured using the immersion test.

861

${ }^{\mathrm{b}}$ Yield tensile strength $f_{y}$.

862

${ }^{\mathrm{c}}$ Ultimate tensile strength $f_{f u}$.

863

${ }^{\mathrm{d}}$ Calculated based on the area of GFRP bars obtained from the immersion test.

864

865

866

867

868

869

870

871

872

873

874

875 
Table 3:Test results of specimens tested under concentric and eccentric axial load

\begin{tabular}{|c|c|c|c|c|c|c|c|c|c|}
\hline \multirow[b]{2}{*}{ Specimen } & \multicolumn{3}{|c|}{ Concentric axial load } & \multicolumn{3}{|c|}{$25 \mathrm{~mm}$ eccentric axial load } & \multicolumn{3}{|c|}{$50 \mathrm{~mm}$ eccentric axial load } \\
\hline & S60E0 & G60E0 & G30E0 & S60E25 & G60E25 & G30E25 & S60E50 & G60E50 & G30E50 \\
\hline Yield load $(\mathrm{kN})^{*}$ & 2596 & 2603 & 2339 & 1728 & 1551 & 1530 & 1143 & 990 & 947 \\
\hline Corresponding axial deformation (mm) & 2.7 & 2.9 & 2.6 & 2.7 & 2.5 & 2.5 & 2.8 & 2.4 & 2.3 \\
\hline First peak load $(\mathrm{kN})$ & 2735 & 2721 & 2398 & 1771 & 1599 & 1572 & 1158 & 1023 & 958 \\
\hline Corresponding axial deformation (mm) & 2.9 & 3.1 & 2.7 & 2.8 & 2.7 & 2.6 & 2.9 & 2.6 & 2.3 \\
\hline Second peak load $(\mathrm{kN})$ & ---- & ---- & 2593 & ---- & ---- & ---- & ---- & ---- & ---- \\
\hline Corresponding axial deformation (mm) & ---- & ---- & 9.1 & ---- & ---- & ---- & ---- & ---- & ---- \\
\hline Ductility & 3.7 & 2.6 & 5.0 & 3.5 & 3.4 & 4.6 & 3.4 & 3.8 & 4.3 \\
\hline Normalized ductility & 1.0 & 0.7 & 1.3 & 1.0 & 0.9 & 1.3 & 1.0 & 1.1 & 1.2 \\
\hline
\end{tabular}

* Calculated based on Pessiki and Peironi (1997)

879

880

881 
Table 4: Test results of specimens tested under four-point loading

\begin{tabular}{lccc}
\hline Specimen & S60B & G60B & G30B \\
\hline Yield load $(\mathrm{kN})^{*}$ & 290 & 311 & 336 \\
Corresponding midspan deformation $(\mathrm{mm})$ & 6.5 & 6.6 & 7.2 \\
First peak load $(\mathrm{kN})$ & 309 & 321 & 350 \\
Corresponding midspan deformation $(\mathrm{mm})$ & 7.5 & 6.8 & 7.6 \\
Second peak load $(\mathrm{kN})$ & ---- & 517 & 637 \\
Corresponding midspan deformation $(\mathrm{mm})$ & ---- & 16.9 & 19.6 \\
Ductility & 4.9 & 5.5 & 6.5 \\
Normalized ductility & 1.0 & 1.1 & 1.3 \\
\hline
\end{tabular}

$887 *$ Calculated based on Pessiki and Peironi (1997)

888

889

890

891

892

893

894

895

896

897

898

899

900

901

902

903 


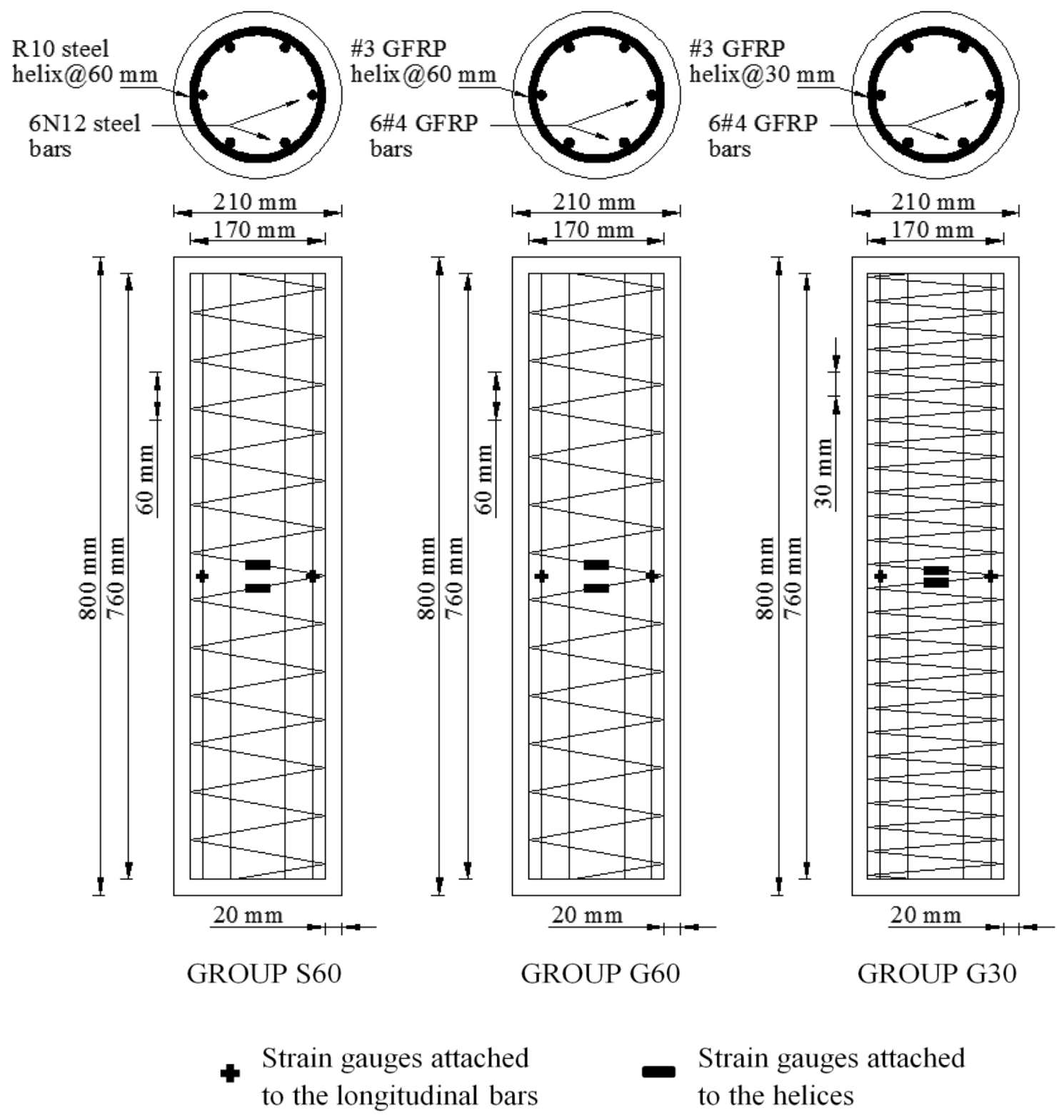

Fig. 1: Dimensions and reinforcement details of the tested specimens 


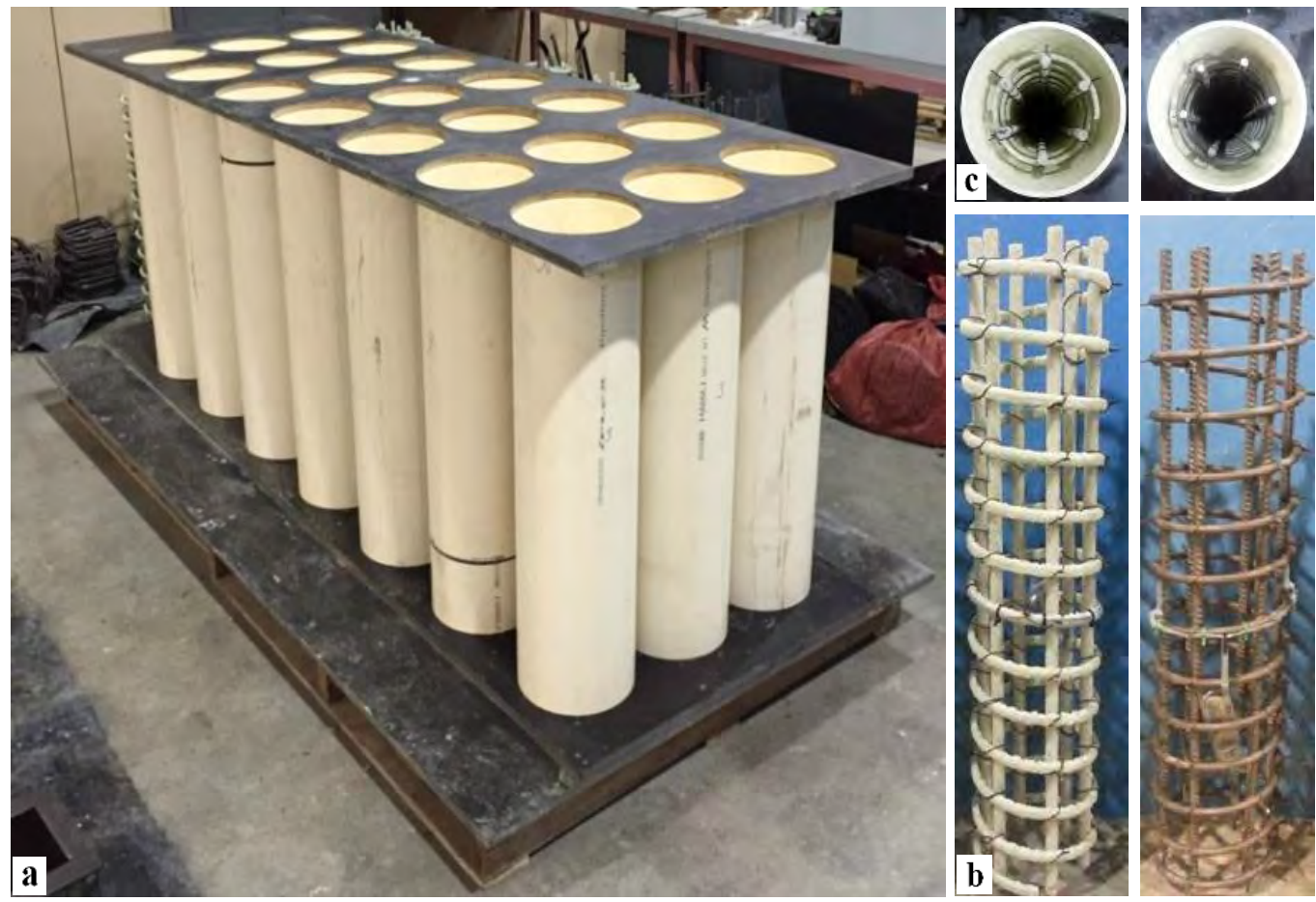

Fig. 2: Specimen Fabrication: (a) PVC molds and the wooden formwork; (b) steel and GFRP cages and (c) GFRP and steel cages inside the PVC molds 

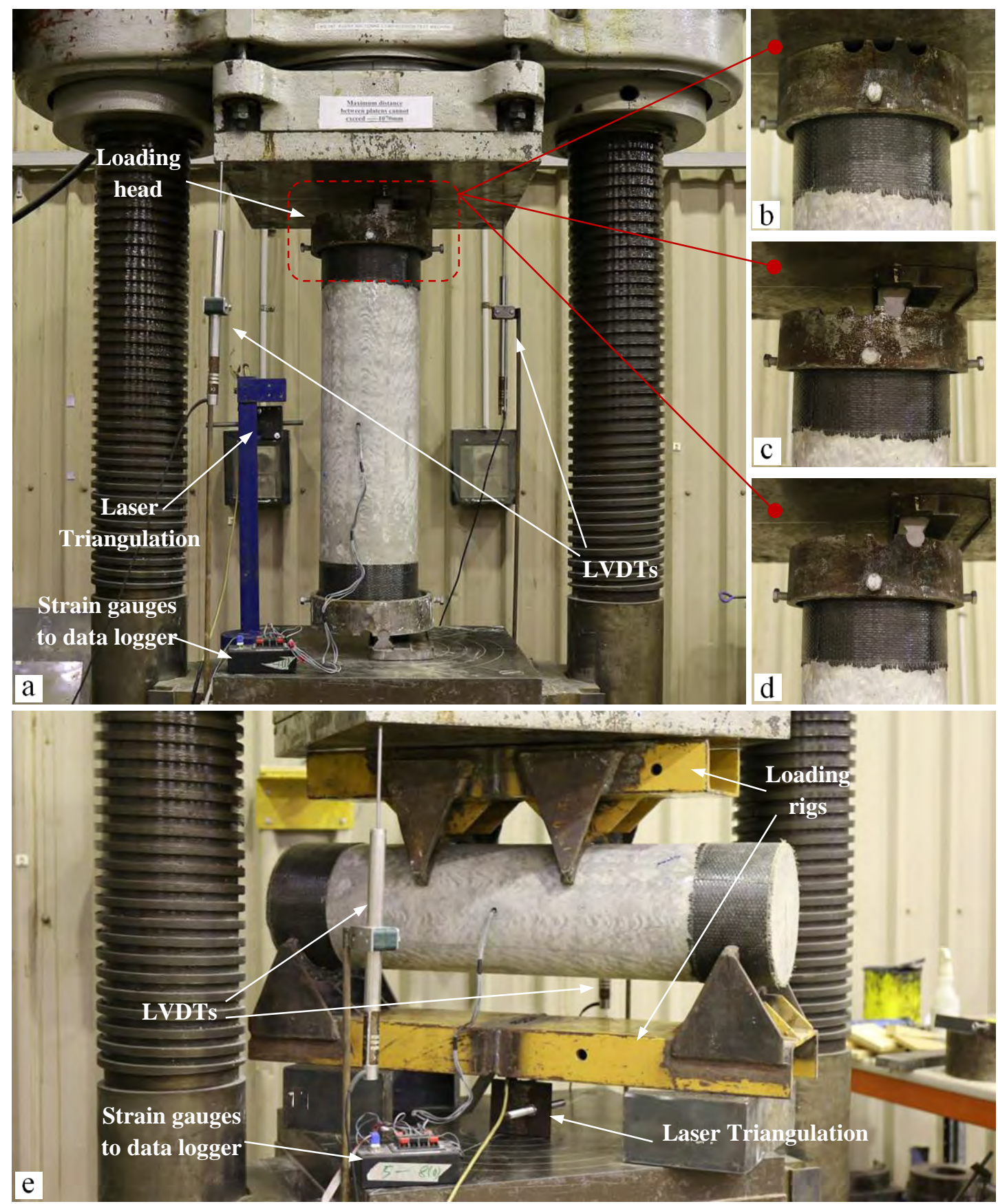

Fig. 3: Testing of the specimens: (a) test setup of column specimens; (b) loading head setup for concentrically loaded column specimens; (c) loading head setup for column specimens tested under $25 \mathrm{~mm}$ eccentric axial load; (d) loading head setup for column specimens tested under $50 \mathrm{~mm}$ eccentric axial load and (e) test setup of the beam specimens. 


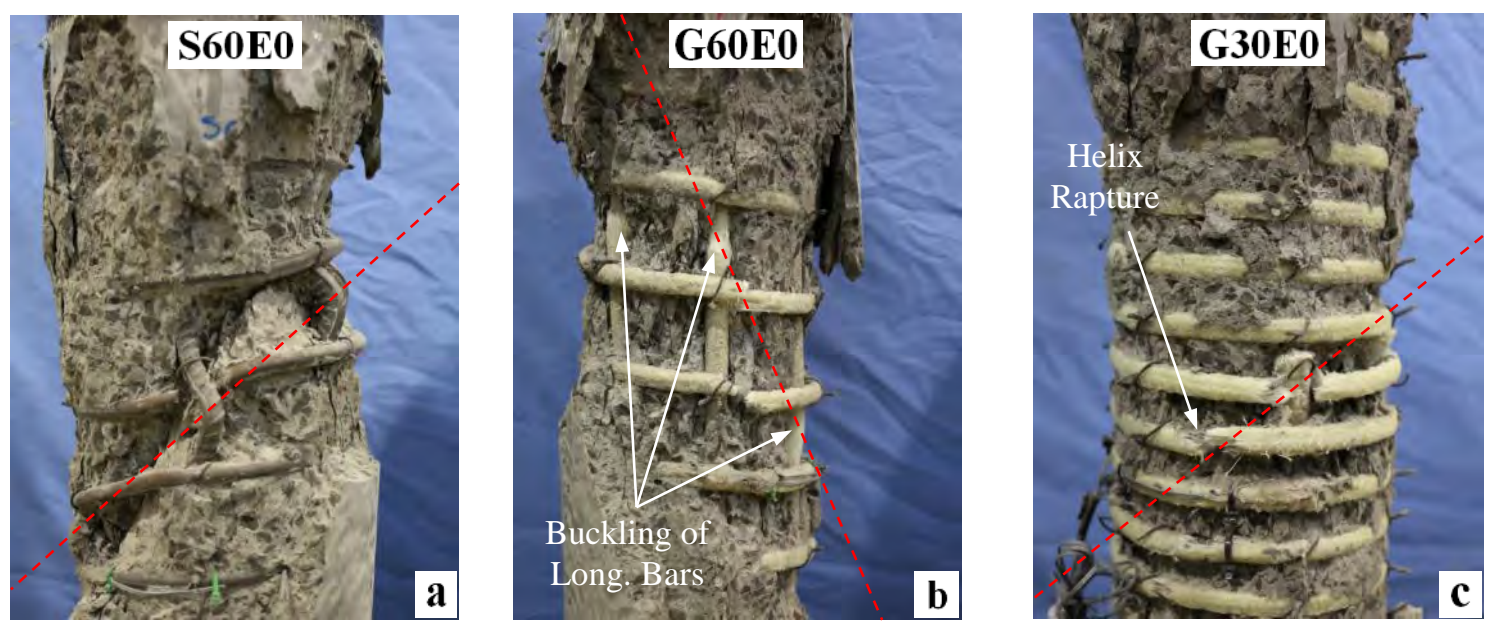

Fig. 4: Failure of column specimens: (a) buckling of the longitudinal steel bars and rupture of the steel helix; (b) buckling and rupture of longitudinal GFRP bars and (c) rupture of the GFRP helix 

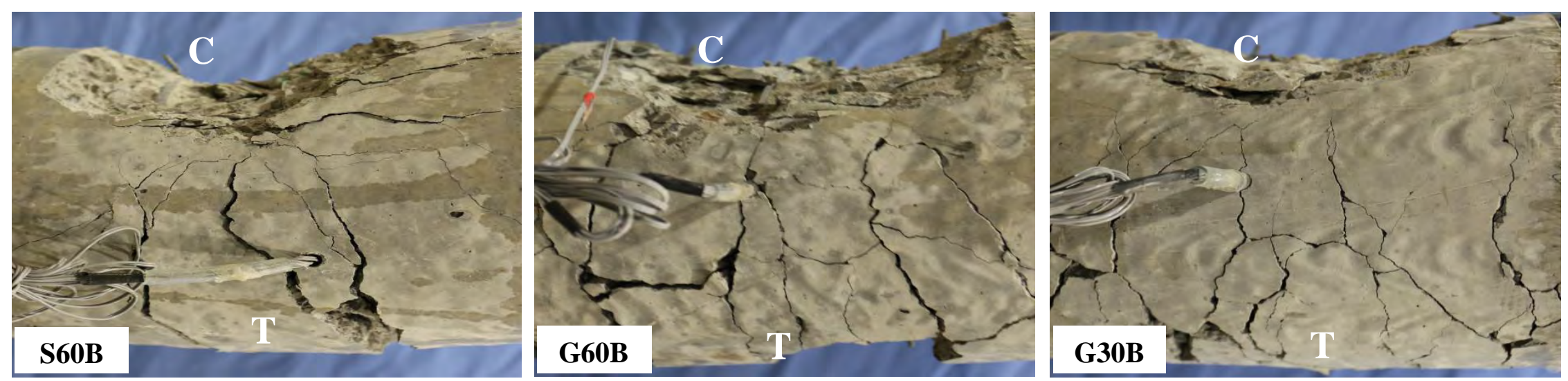

Fig. 5: Failure modes of the beam specimens; $\mathrm{C}$ is the compression face and $\mathrm{T}$ is the tension face. 


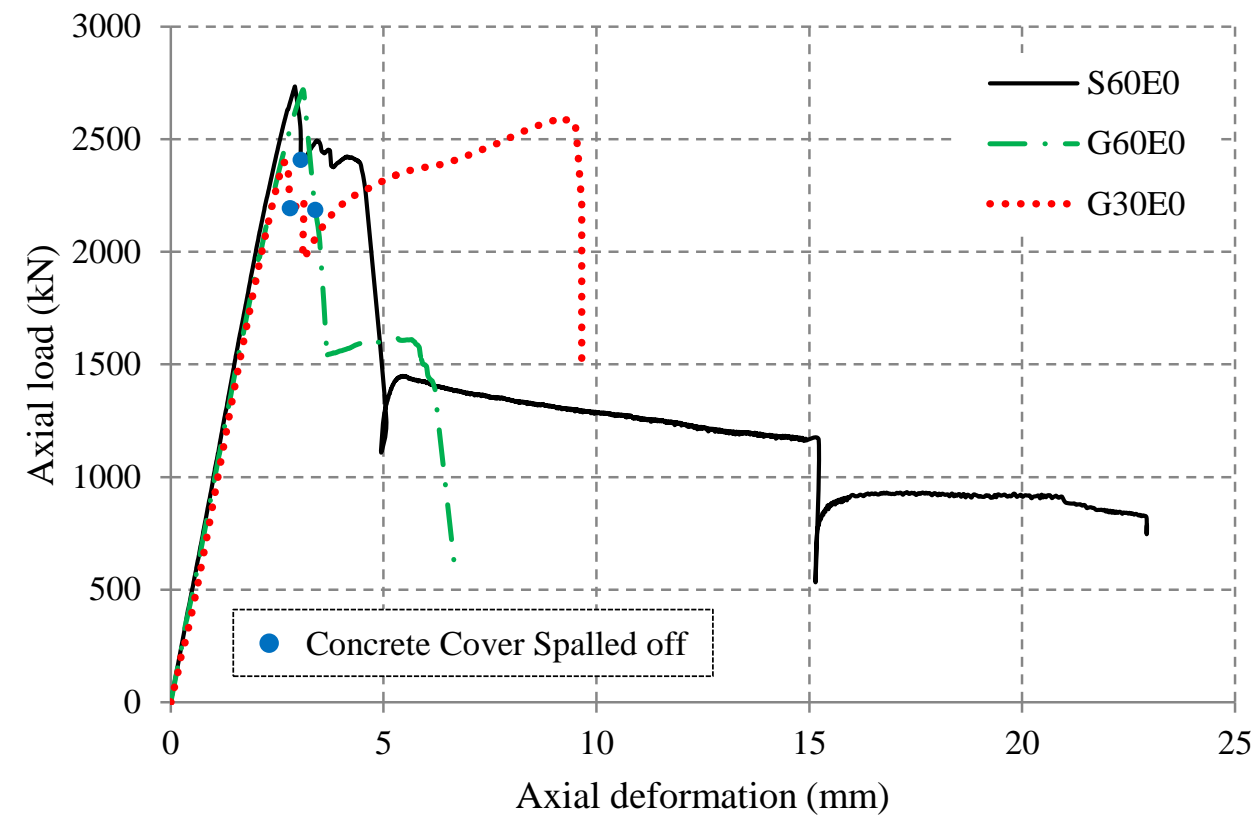

Fig. 6: Axial load-axial deformation behavior of the concentrically loaded specimens 

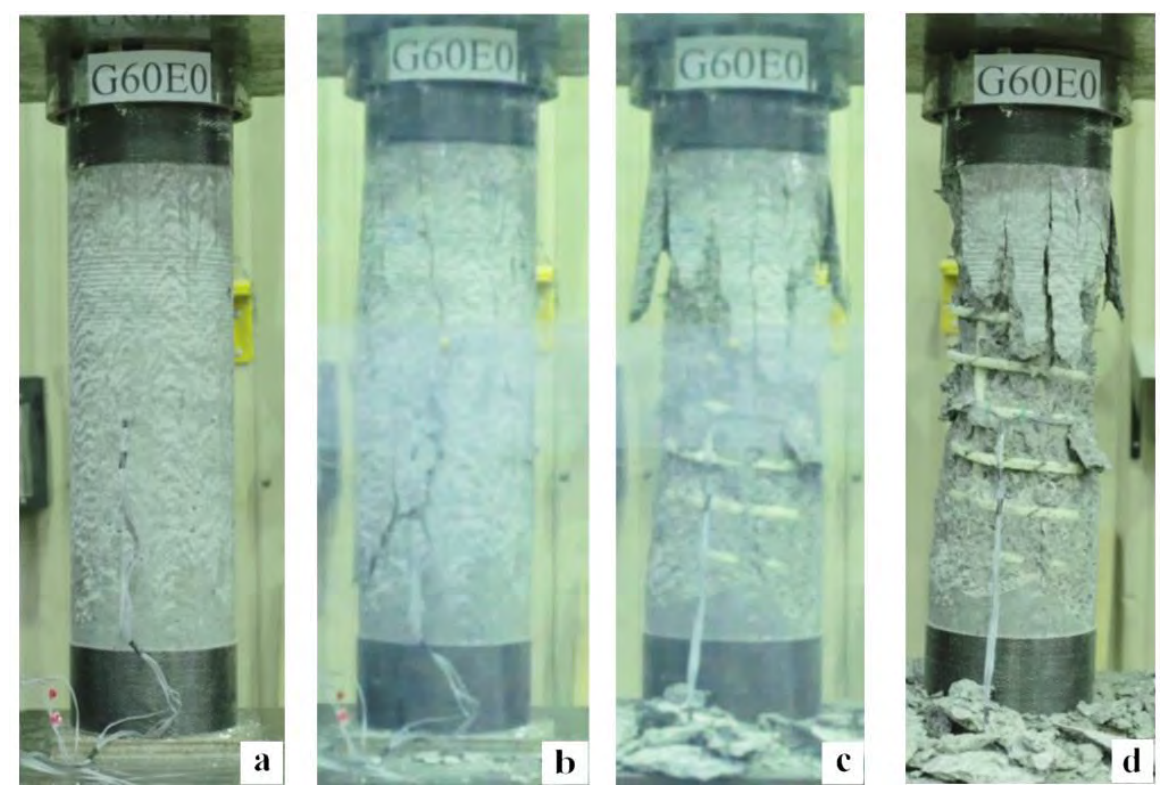

Fig. 7: Specimen G60E0 at different loading stages: (a) at the beginning of the test; (b) after the first peak load; (c) spalling of the concrete cover and (d) after failure 


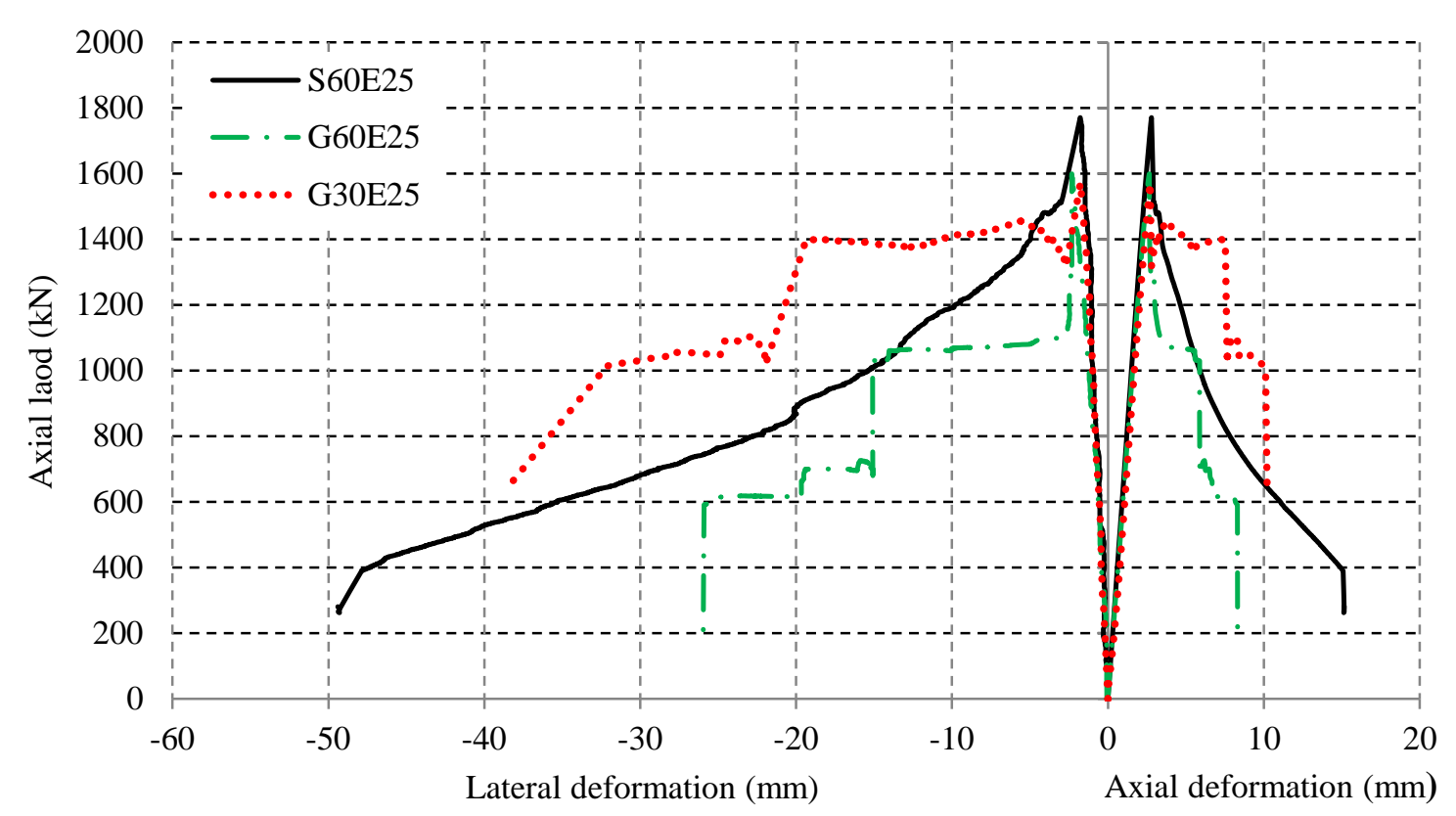

(a)

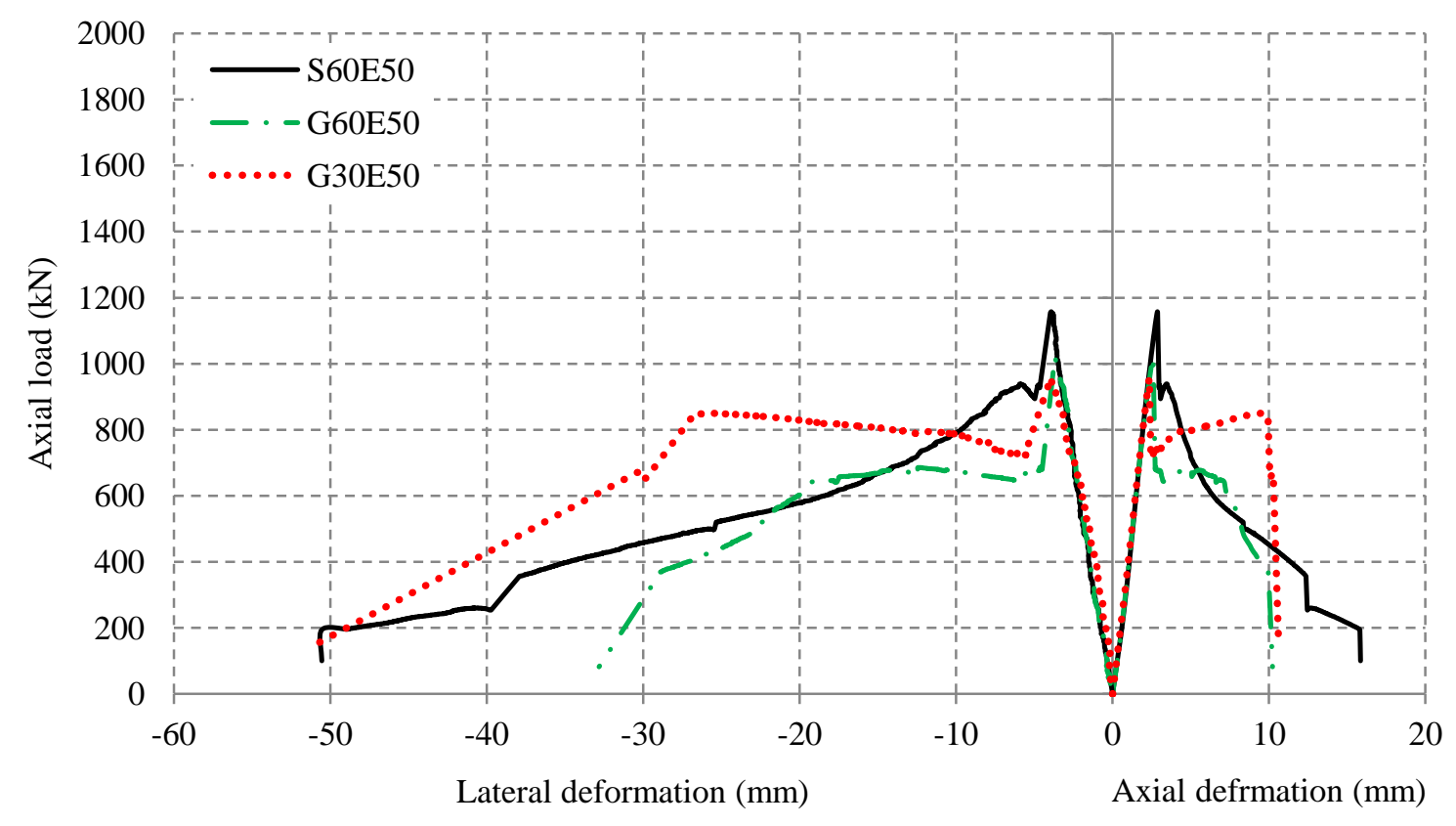

(b)

Fig. 8: Axial load-axial deformation and axial load-lateral deformation behavior of the specimens tested under: (a) $25 \mathrm{~mm}$ eccentric axial load and (b) $50 \mathrm{~mm}$ eccentric axial load 


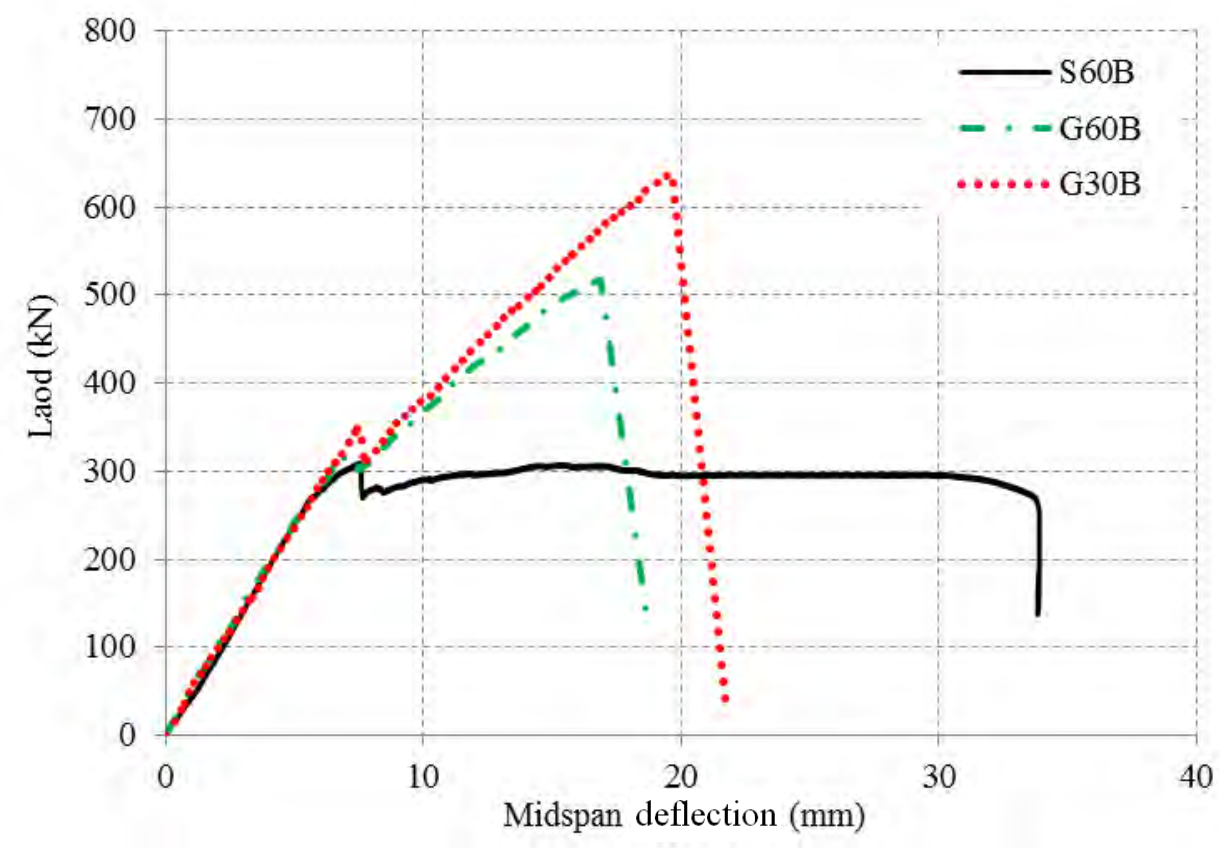

Fig. 9: Load-midspan deflection behavior of the specimens tested under four-point loading 


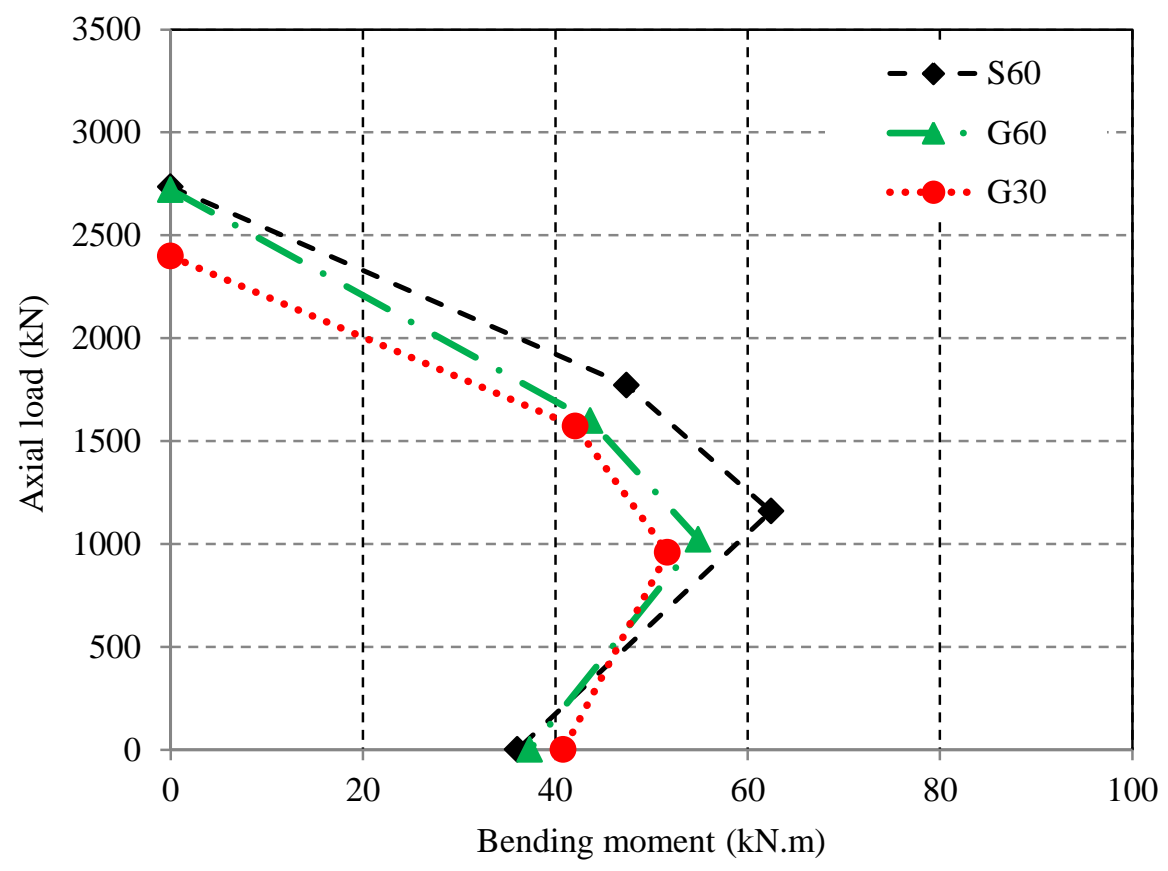

Fig. 10: Experimental axial load-bending moment $(P-M)$ interaction diagrams 


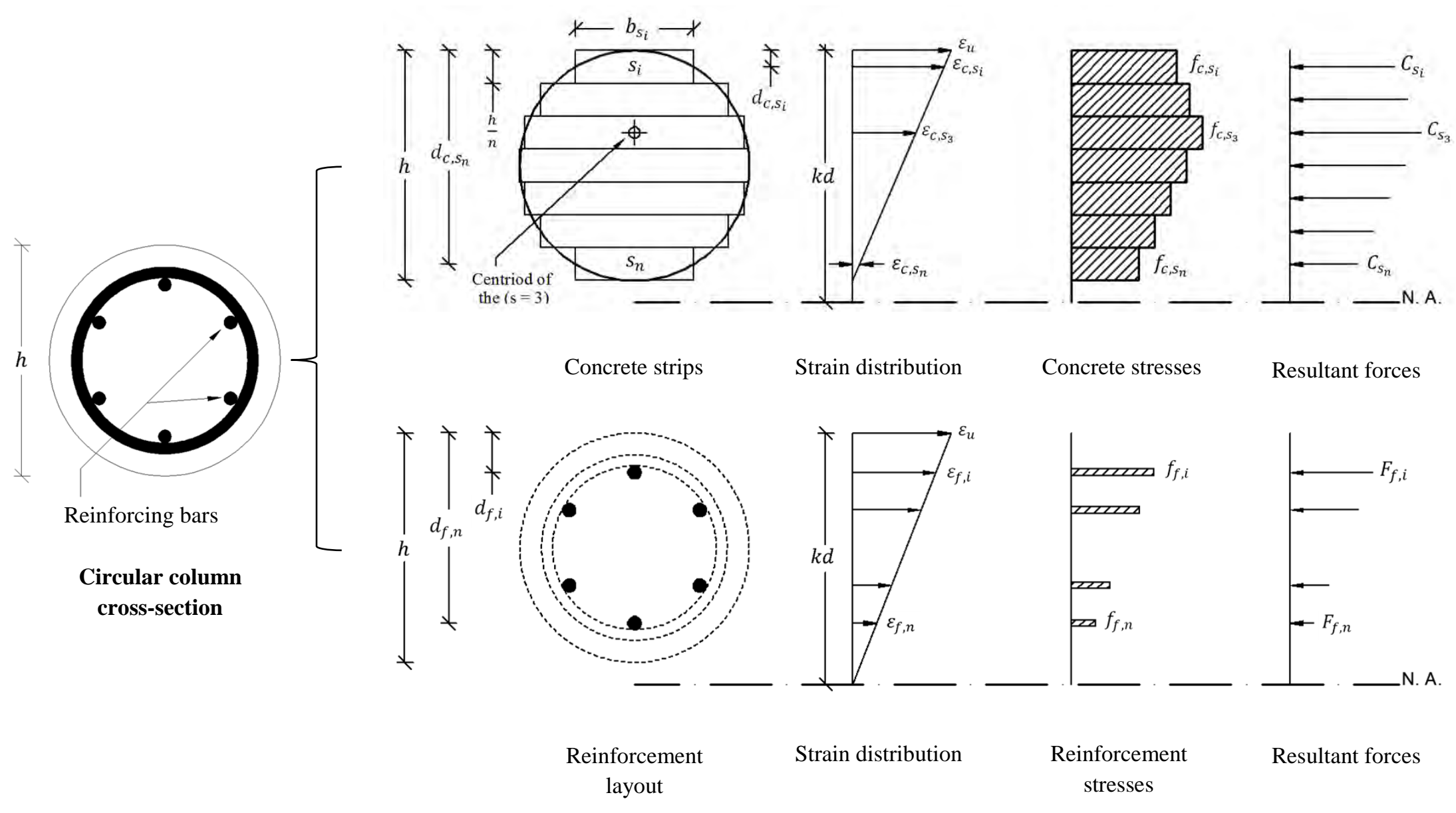

Fig. 11: Stress-strain distribution for $P-M$ interactions of GFRP-HSC cross-section using layer-by-layer integration 

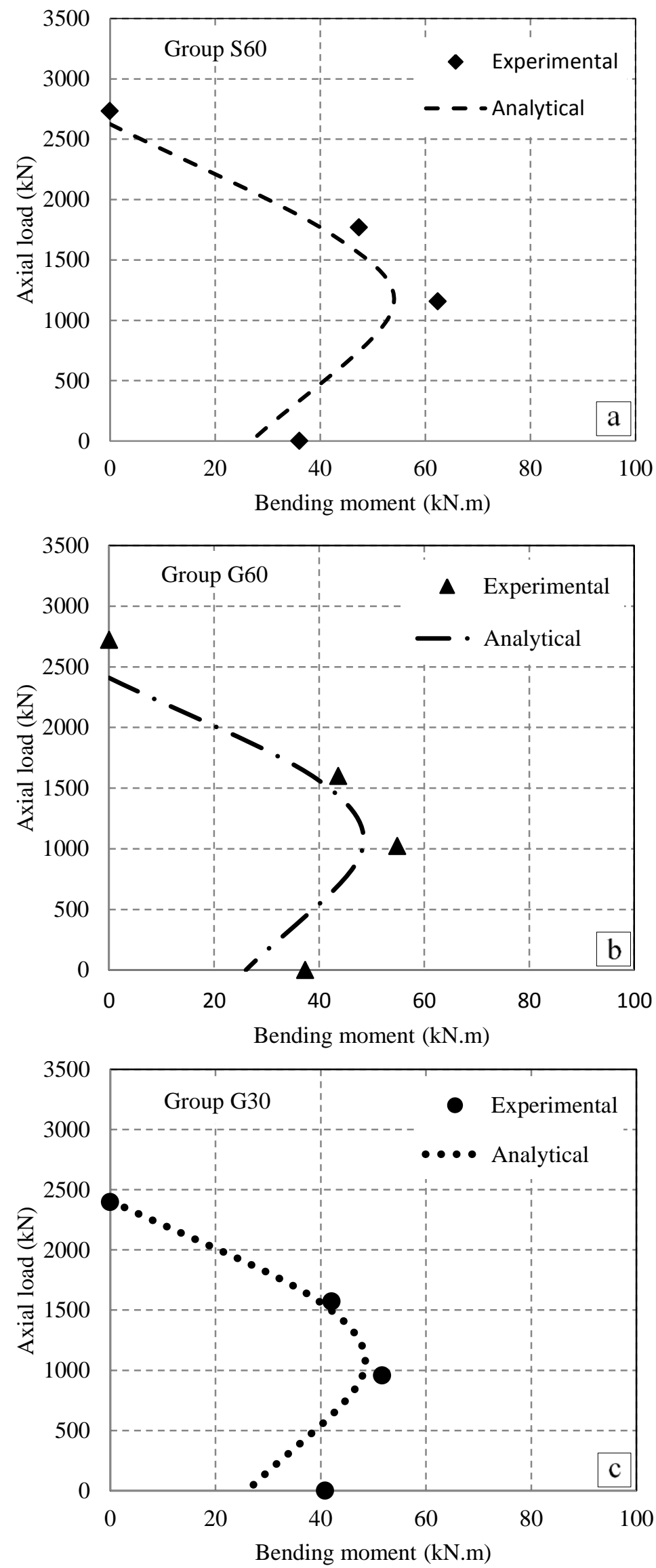

Fig. 12: Experimental and analytical axial load-bending moment $(P-M)$ interaction diagrams for: (a) Group S60; (b) Group G60 and (c) Group G30 